\title{
Does Compliance Pay? Social Standards and Firm-level Trade
}

\author{
Greg Distelhorst \\ Richard M. Locke
}

January 10, 2018

American Journal of Political Science

Running title: Does Compliance Pay?

Keywords: political economy, trade, labor, regulation, global supply chains.

Contact information:

Greg Distelhorst (corresponding author), Assistant Professor of Global Economics and Management, MIT Sloan School of Management, 77 Massachusetts Avenue E62425, Cambridge, MA 02139, gregd@mit.edu.

Richard M. Locke, Provost and Professor of Political Science and Public and International Affairs, Brown University, Box 1862, Providence, RI 02912, richard_locke@brown.edu.

We are grateful to our collaborators at the sourcing agency and several manufacturing establishments for providing access to administrative data and participating in interviews for this research. Thanks to Matthew Amengual, Vincent Arel-Bundock, Stephanie Barrientos, Cristina Bodea, Rafael Gomez, Rebecca Henderson, Mitchell Hoffman, Simon Johnson, Alexander Kuo, Thomas Kochan, Daniel Mattingly, Layna Mosley, Khalid Nadvi, Kelly Pike, Dennis Quinn, Chuck Sabel, Andrew Schrank, Michael Toffel, Kristin Vekasi, Christopher Woodruff and seminar participants at the International Political Economy Society, Association for Research on Corporate Sustainability, Canadian Industrial Relations Association, the Labor and Employment Relations Association, Brown University, University of Edinburgh, University of Manchester, MIT, and University of Toronto for helpful feedback on this study. We wish to thank Sharlene Song for excellent research assistance and the MIT Sloan School of Management Dean's Innovation Fund for providing travel and research support. 


\begin{abstract}
What is the relationship between trade and social institutions in the developing world? The research literature is conflicted: importing firms may demand that trading partners observe higher labor and environmental standards, or they may penalize higher standards that raise costs. This study uses new data on retailers and manufacturers to analyze how firm-level trade responds to information about social standards. Contrary to the "race to the bottom" hypothesis, it finds that retail importers reward exporters for complying with social standards. In differencein-differences estimates from over two thousand manufacturing establishments in 36 countries, achieving compliance is associated with a $4 \%[1 \%, 7 \%]$ average increase in annual purchasing. The effect is driven largely by the apparel industry - a longterm target of anti-sweatshop social movements - suggesting that activist campaigns can shape patterns of global trade.

Replication materials. The data, code, and any additional materials required to replicate all analyses in this article are available on the American Journal of Political Science Dataverse within the Harvard Dataverse Network, at:

http://dx.doi.org/10.7910/DVN/2E2M9Z
\end{abstract}

Word count: 9,109 
International trade shapes not only economic growth but also the social institutions of trading countries. A research literature in political economy, going back at least to Marx's argument that free trade accelerates exploitation of labor and the collapse of capitalism (Engels 1888), debates both the mechanisms and direction of its impact. Contemporary scholarship has explored how international trade shapes taxation (Garrett 1998), social spending (Rodrik 1998; Rudra 2008; Ansell 2008; Rickard 2012), health and environmental regulations (Vogel 1995; Drezner 2001), and labor rights (Rudra 2005; Neumayer and De Soysa 2006; Mosley and Uno 2007; Greenhill, Mosley and Prakash 2009; Mosley 2010).

This study contributes new evidence on one mechanism linking trade and social institutions: the market behavior of trading firms. If traders reward exporters that exhibit lower labor and environmental standards, their behavior creates downward pressure on these standards, contributing to a trade-led "race to the bottom." On the other hand, if trading firms prefer doing business with exporters that observe higher standards, they may create incentives for exporters to improve standards. These firm-level mechanisms are distinct from state-level mechanisms linking trade to social institutions. Yet previous empirical research focuses largely on aggregate national-level policies and labor market outcomes. The contribution of firm-level mechanisms is therefore unknown.

We investigate how the social standards of exporters correlate with firm-level trade. Examining retailers in advanced economies and several thousand manufacturers in emerging markets, we detect surprising evidence of a preference for exporters that observe higher standards. Importers purchase more from export factories that comply with basic labor and environmental standards, contrary to what we would expect from a firm-level race to the bottom. Difference-in-differences estimates show that within-exporter improvements in compliance are associated with increased average order volume of $4 \%[1 \%, 7 \%]$, even after adjusting for variation in manufacturing performance. These findings suggest that in the markets we study either (a) compliance with basic labor and environmental standards can be achieved without sacrificing performance on price, delivery, or product quality, or (b) some importers are willing to pay more to trade with socially compliant exporters.

The study cannot conclusively adjudicate between these interpretations. However, noting that the importers we study are primarily retailers and apparel brands headquartered in advanced economies, we propose that anti-sweatshop social movements may have prompted them to prefer purchasing from factories that comply 
with basic social standards. Consistent with this hypothesis, we find that the relationship between compliance and sourcing appears primarily in apparel, an industry targeted by anti-sweatshop activism over the last three decades. Yet enforcing basic standards through this mechanism has clear limitations. A majority of the studied exporters remain noncompliant with basic standards. Despite evidence of a firm-level preference for compliance, this incentive falls far short of guaranteeing basic labor and environmental standards in global supply chains.

In addition to the research literature on trade and social standards, this study contributes to longstanding debates surrounding the efficacy of "private regulation" or "civic regulation" of multinational business (Elliott and Freeman 2003; O'Rourke 2003; Mattli and Büthe 2005; Bartley 2007; Vogel 2008; Mayer and Gereffi 2010; Locke 2013). Private regulation refers to non-state systems of monitoring and enforcement of standards. As these institutions have become increasingly prevalent, scholars have debated the extent and conditions under which private regulation can supplement or even replace regulation by the state. Early scholarship suggested that private regulation - supported by consumer and activist pressure - could drive higher standards in trading jurisdictions that fell outside the reach of trade unions and effective regulatory agencies (Fung, O'Rourke and Sabel 2001; Elliott and Freeman 2003). Yet subsequent empirical research cast doubt on the efficacy of private regimes, finding that major labor and environmental violations persisted in exporters subject to private regulation (Vogel 2005; Locke, Qin and Brause 2007; Seidman 2007; Locke, Amengual and Mangla 2009; Distelhorst et al. 2015).

Although previous research shows that many exporters fail to achieve compliance with international codes of conduct, it is less informative about the economic incentives created by transnational private regulation. Do these incentives reward improving or declining standards? Our study affirms that many noncompliant factories participate in global supply chains, yet our findings also suggest that economic incentives within these supply chains generate upward pressure on standards. Within an industry subject to pressure from anti-sweatshop activism, exporting firms are on average rewarded rather than punished for improving compliance with labor and environmental standards. The concluding section discusses the magnitude of this effect and the investments in socially responsible practices it might offset. 


\section{Trade-based diffusion of social institutions}

The political economy literature is conflicted about the effects of trade on worker rights and environmental protection. Some theories hold that pressures from international competition undermine costly protections for both workers and the environment in a race to the bottom. Others suggest that international trade leads to upward harmonization on standards, resulting in "California effects." Yet uncertainty surrounds not only the direction of trade's impact, but also the mechanisms that produce these effects.

To date, a significant body of research focuses on country-level mechanisms and outcomes. Falling tariffs may foster competition between national economies that extends to regulatory regimes. If domestic regulations impose cost disadvantages on industry, governments may reduce regulation to protect domestic tax revenue and employment (Drezner 2001). Several country-level empirical studies find that trade openness undermines worker rights and bargaining power, especially in developing countries (Mosley and Uno 2007; Rodrik 1997; Rudra 2005, 45-46). Yet alternative measurement and identification strategies find either no relationship or the opposite effect (Neumayer and De Soysa 2006; Vadlamannati 2015).

Another body of research notes that trade liberalization is often accompanied by a negotiated harmonization of regulatory standards. When powerful states also have higher standards, they may impose those standards on their trading partners, leading to upward harmonization through trade liberalization (Vogel 1995). Indeed, since 1950 roughly two-thirds of all preferential trade agreements include provisions on social institutions, including labor rights, environmental protection, and human rights (Hafner-Burton 2005; Milewicz et al. 2016). Country-level research on trade also offers evidence of these "California effects" in both labor rights (Greenhill, Mosley and Prakash 2009) and human rights (Cao, Greenhill and Prakash 2013).

\section{Firm-level mechanisms}

The mechanisms discussed above function at the country-level through changes in policy. Yet the market behavior of trading firms - rather than governments - may generate similar pressures on labor and environmental practices. Managers decide which firms they do business with, how to compensate workers, and how to dis-

pose of the waste they generate. The effects of trade therefore depend not only on 
how governments behave, but also on whether firms that observe higher regulatory standards are rewarded or penalized by global markets.

One possibility is that firms that observe higher standards-like offering higher wages or paying to mitigate their environmental impacts - are at a competitive disadvantage in export markets. This view rests on two assumptions. The first assumption is that, other things equal, observing higher labor and environmental standards results in increased unit prices. For example, if an exporting firm increases employee compensation to satisfy minimum wage regulations, it may pass increased labor costs to its customers in the form of higher prices. The second assumption is that customers (importers) are indifferent to the labor and environmental standards of their suppliers. They are unwilling to pay higher prices to do business with compliant exporters. Under these two conditions, we may observe a firm-level race to the bottom as exporters seek price advantages by reducing compliance with labor and environmental regulations $(\operatorname{Rodrik} 1997$; Chan 2003; Mosley and Uno 2007; Weil 2014).

Alternatively, there is the possibility of firm-level "California effects." Like states, trading firms may also have preferences about the processes through which the goods they import are produced. Activist campaigns are one possible driver of these preferences. Social movements promoting environmental sustainability and combatting worker exploitation attract consumer attention and threaten the value of targeted firms (Fung, O'Rourke and Sabel 2001; Elliott and Freeman 2003; Vogel 2005; Bartley 2007; King and Soule 2007; Seidman 2007). Reputation-conscious importers may therefore prefer to do business with exporters that comply with minimum standards in labor and environmental practices. This firm-level preference would allow trade to drive higher standards in the absence of any government action.

The emergence of transnational private regulation of global supply chains offers suggestive evidence for this possibility. Activist campaigns around labor and environmental abuses have prompted many consumer-facing multinational enterprises to establish "supply chain responsibility" programs (Vogel 2005; Bartley 2007; Vogel 2008; Mayer and Gereffi 2010; Levi et al.|2013; Locke 2013; Toffel, Short and Ouellet 2015). This typically entails establishing codes of conduct that govern working conditions, environmental practices, and other international standards. Exporters seeking to do business with these multinationals must agree to these standards and submit to periodic audits. Private regulation of supply chains has spread from apparel and 
footwear to varied industries including consumer electronics (Distelhorst et al. 2015 ; Nadvi and Raj-Reichert 2015), food and beverages (Coslovsky and Locke 2013), and forestry (Bartley 2007). 1 Unlike Fair Trade certification (De Janvry, McIntosh and Sadoulet 2015), these compliance programs seek primarily to alter the production processes of exporters, not necessarily increase their profits.

In comparison to the research literature on trade and social institutions at the country-level, there is markedly less evidence on firm-level mechanisms (Figure 1). The studies discussed in the previous section primarily use cross-national datasets developed by Mosley (2010) and Kucera (2001) to measure the prevalence of labor rights violations aggregated at the national level. These outcomes may be influenced by state-level mechanisms, firm-level mechanisms, or a combination of the two.

[Figure 1 here]

Although previous research does not offer quantitative evidence on firm-level mechanisms, scholarship on transnational private regulation casts doubt on its efficacy. Studies have repeatedly found that noncompliant export factories remain in supply chains even after multiple audits and corrective exercises (Locke, Qin and

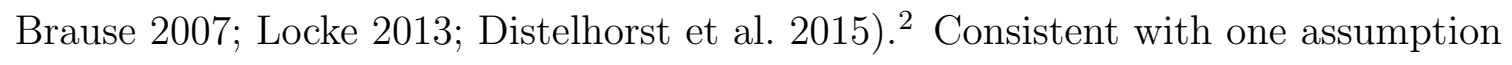
of the firm-level race to the bottom, these studies affirm that complying with higher process standards - paying statutory minimum wages and benefits, mitigating pollution impacts, and offering safe factory infrastructure - increases costs (Mosley 2010; \begin{tabular}{|l|l|l|}
\hline Ruwanpura and Wrigley|2011; & Barrientos $2013 ;$ & Lund-Thomsen and Lindgreen 2014).
\end{tabular} Despite evidence that some consumers pay premiums for ethically produced goods (Hainmueller, Hiscox and Sequeira 2015), this scholarship also affirms the second assumption, that importers are unwilling to pay more to do business with compliant factories: "It seems inevitable that higher labor standards will increase production costs, and many suppliers believe that addressing [social responsibility] issues makes them less competitive" (Vogel 2005). Consistent with this view, reports by scholars, activists, and NGOs continue to expose poor working conditions in export factories

\footnotetext{
${ }^{1}$ Although we have separated state-level and firm-level mechanisms in this discussion, private regulation does not operate in a regulatory vacuum. There are complementarities between transnational private regulation and domestic state-based regulation Amengual 2010 Coslovsky and Locke 2013 Amengual and Chirot 2016).

${ }^{2}$ In contrast to most of the literature, Harrison and Scorse (2010) found that the Indonesian export industries most exposed to anti-sweatshop campaigns in the 1990s raised worker wages with no discernible impact on employment.
} 
manufacturing for top retail brands, even when these factories are subject to codes of conduct and compliance auditing by their customers (Chan, Pun and Selden 2013; Workers Rights Consortium 2014).

Despite the sensibility of these critiques, empirical evidence on firm-level trade and social institutions has been elusive. One noteworthy exception, Oka (2012), found that reputation-conscious importers rewarded compliance by Cambodian exporters with long-term sourcing relationships. However, this finding came from a unique institutional setting - the Better Factories Cambodia program ${ }^{3}$ raising questions about its generalizability to exporters who cannot or do not participate in such programs.

\section{Research Design}

If global supply chains exhibit a firm-level race to the bottom in labor and environmental standards, importers should place more orders with low-standards exporters. Yet there is also the possibility of firm-level California effects; if trading firms prefer doing business with exporters that comply with higher labor and environmental standards - and the effect of compliance on prices is either negligible or tolerable - we expect the opposite pattern.

We test these hypotheses using a novel dataset on export transactions involving several thousand establishments provided by a global sourcing agent 4 Sourcing agents play an important role in global supply chains by connecting importers with exporters capable of producing goods at an acceptable price, quality level, and delivery schedule. The sourcing agent we study primarily serves retailers and wholesalers headquartered in advanced economies (Figure 2).

[Figure 2 here]

Contemporary sourcing agents not only facilitate transactions; they also monitor the compliance of exporters in the developing world with labor, environmental,

\footnotetext{
${ }^{3}$ Better Factories Cambodia (http://betterfactories.org/) is a factory monitoring and capabilitybuilding program managed by the International Labour Organization and the International Finance Corporation.

${ }^{4}$ The sourcing agent's data were obtained and analyzed under the terms of a research agreement. The agreement allowed the sourcing agent to mask its name and the names of its customers and supplier factories in any published research.
} 
and legal standards. In response to importer demand, the sourcing company established its own code of conduct, audited export factories for compliance with this code, and reported the results to prospective importers. We use these factory audits to measure exporter compliance with labor and environmental standards. Social compliance auditing has many well-understood problems. Audits only capture a snapshot of factory conditions, are only as good as the training of their auditors, and are poorly-suited to evaluate and enforce process rights like the freedom of association (O'Rourke 2003; Locke, Amengual and Mangla 2009; Anner 2012). Rather than assume that audits offer a flawless picture of factory conditions, this study adopts the more modest assumption that factories that exhibit higher compliance scores are also, on average, more compliant than those that exhibit lower scores. In the online supplement, we examine detailed audit result to help readers understand what issues auditors actually detect and ensure our results are not driven by noncredible items like freedom of association or non-discrimination. However, even if readers remain skeptical of this approach, these audits serve as the primary source of information available to potential importers about exporter labor and environmental practices. Audit results are therefore an appropriate measure of exporter compliance as perceived by importers.

Auditors inspect factories over one to two days to evaluate their practices against the standards established in the code of conduct. They then assign the factory a letter grade on the scale "A" through "D". The factories are also summarized in thirteen separate compliance areas, such as "wages and benefits" and "work hours" (Appendix Table A1). Factories rated A and B (28\% of the factory-year observations in the main panel) are considered compliant, whereas those rated $\mathrm{C}$ and $\mathrm{D}$ are noncompliant. Our analysis uses both the original four-point grading system and this binary distinction between compliance and noncompliance, which eliminates the assumption of equidistance between the four letter grades.

The sourcing agency also provided data on the value of customer orders placed at each export manufacturer. These records were provided in annual sums and binned into thirteen ranges, from under USD 50,000 to over USD 50 million 5 The midpoint of each bin provides an estimate of the annual nominal value of buyer orders. These

\footnotetext{
${ }^{5}$ The boundaries of the thirteen annual order value bins were $\$ 0, \$ 50 \mathrm{k}, \$ 100 \mathrm{k}, \$ 250 \mathrm{k}, \$ 500 \mathrm{k}, \$ 750 \mathrm{k}$, $\$ 1 \mathrm{~m}, \$ 5 \mathrm{~m}, \$ 10 \mathrm{~m}, \$ 20 \mathrm{~m}, \$ 30 \mathrm{~m}, \$ 40 \mathrm{~m}, \$ 50 \mathrm{~m}$, and over $\$ 50 \mathrm{~m}$. In addition to estimated annual order values, Appendix Table A5 reports fitted linear probability models of exceeding the thresholds defined by bin edges.
} 
estimates are then deflated to obtain order value in constant 2012 dollars 6 Within this sample, most exports come from countries with poor freedom of association and protection of labor rights (Figure 3).

[Figure 3 here]

In addition to annual order values and factory compliance data, the sourcing agent provided information on factories' locations, product types, delivery performance, and product quality. Descriptive statistics on all variables appear in Appendix Table A1. The export factory panel is composed of factories with valid compliance, order value, and manufacturing performance data in at least two years over 2009-2012. The sourcing agent only records factory on-time delivery and quality performance in years that it places orders at that factory. Therefore the main panel represents only a subsample of the entire population of exporting factories. To ensure that findings are not idiosyncratic to factories with manufacturing performance data, a second analysis examines all factories that appear in at least two years of the panel.

Studying trade and social institutions in this sample has both advantages and disadvantages. These exporter-importer transactions offer an appealing behavioral measure of the economic incentives surrounding labor and environmental standards: the decision by importers to place orders at factories. In contrast to previous studies examining worker rights outcomes at the national level, this analysis isolates mechanisms operating at the firm level. Factory compliance with standards is measured by inspections conducted by external auditors, rather then self-reporting by factory management through surveys. In addition, the panel structure of these data offers an opportunity to control for unobserved time-invariant features of factories and geographies. Finally, because the sourcing agent works with hundreds of importers these empirical results also have improved external validity over the single-importer studies that dominate the existing literature on transnational private regulation. $]^{7}$

\footnotetext{
${ }^{6}$ Deflators for USD-denominated orders were obtained from the Bureau of Labor Statistics' Import Price Index series for "Consumer Goods, Excluding Automotives" (http://www.bls.gov/web/ximpim/beaimp.htm, accessed Oct 26, 2015). Analyzing non-deflated nominal currency data does not significantly alter the results.

${ }^{7}$ One notable exception is Toffel, Short and Ouellet (2015), who analyze factory compliance in a multi-importer context and find that prosocial attitudes and economic development in the home countries of importers are associated with improved factory compliance with social standards.
} 
At the same time, this study is not a census of global supply chains. The importers studied are primarily retailers, and apparel manufacturers account for $58 \%$ of the exporter panel. This industry has been a target of anti-sweatshop campaigns, a fact we exploit when exploring mechanisms. However, this suggests that results are generalizable only to particular industries, not all global supply chains. In addition, confidentiality considerations led the sourcing agency to provide only annual order value at each factory. We therefore cannot decompose firm-level trade into quantities and prices. This constrains analysis of the economic implications of our findings, as discussed in the concluding section.

\section{Firm-level trade and exporter compliance}

Do importers prefer exporters with higher or lower workplace standards? We find that compliant factories receive markedly more business than noncompliant factories (Table 1). In 2012, 21\% were rated compliant in at least half of their audits (some factories are audited multiple times in a single year). On average, these factories received $64 \%$ greater order value than those rated noncompliant. Average buyer spend was USD 4.1 million in compliant factories, compared to USD 2.5 million in noncompliant factories. Adjusted for factory size, compliant factories received $\$ 6,080$ in orders per employee whereas non-compliant factories received $\$ 4,310$.

$$
\text { [Table } 1 \text { here] }
$$

The rewards for compliance appear large in this cross-sectional analysis. However, this comparison may not represent a credible estimate of the relationship between compliance and importer purchasing decisions. Table 1 also compares other qualities of compliant and noncompliant factories in 2012. They differ in many ways. Chinese, Bangladeshi, and Indonesian factories are more likely to be found in the noncompliant group. Compliant factories are more likely to manufacture clothing, employ roughly one hundred (17\%) more people on average, and exhibit superior quality and on-time delivery performance.

Fitting an OLS model of order value using all variables in Table 1 as predictors estimates smaller effects of factory compliance on orders: an increase of USD 926 thousand (Appendix Table A3). This estimate is more credible than the previous comparison, but it cannot exclude the possibility that unobserved factory-level differences correlated with compliance levels are biasing effect estimates. For example, it seems likely that - even after controlling for factory size and performance 
in on-time delivery and product quality - compliant factories may also enjoy advantages in management practices, human capital, or technology that support superior productivity (Bloom et al. 2013).

To account for time-invariant differences (country, product type, ownership, etc.) across factories, we use the panel structure of the data to generate withinfactories estimates of the effect of changes in exporter compliance status on importer purchasing behavior. The effect of compliance on orders is estimated by fitting a standard two-way fixed effects regression model, both with and without time-varying factory performance metrics.

$$
\begin{gathered}
Y_{i t}=\eta_{i}+\delta_{t}+\beta_{1} \text { Compliance }_{i t}+\varepsilon_{i t} \\
Y_{i t}=\eta_{i}+\delta_{t}+\beta_{1} \text { Compliance }_{i t}+\beta_{2} \text { OnTime }_{i t}+\beta_{2} \text { Quality }_{i t}+\varepsilon_{i t} .
\end{gathered}
$$

Each model is fit using both the binary measure of compliance and the annual average of the 4 -point compliance score $(\mathrm{A}=3, \mathrm{~B}=2, \mathrm{C}=1, \mathrm{D}=0)$ as explanatory variables. The left-hand panel of Table 2 (columns 1-4) fits these models using the main factory panel summarized in Appendix Table A1. The center panel (columns 5-8) fits the same models on the subsample of factories that undergo changes in compliance status during the period studied.

Under the twin assumptions that compliance raises unit prices and that importers will not pay more to do business with compliant exporters, we expect that when factories raise standards, they should lose business. Instead, we observe the opposite pattern. Across both samples, achieving compliance is associated with an increase in purchasing. This effect holds whether compliance is measured using the raw four-point audit score or the binary compliance simplification. Adding controls for manufacturing performance has almost no impact on effect magnitudes.

As noted above, not all factories have performance, sourcing, and compliance data in at least two years of the panel. The rightmost section of Table 2 therefore expands to include the larger panel of factories that have at least two years of compliance and purchasing data. The main effects strengthen when we expand the sample to include these factories (Columns 9 and 10). In the final two columns, we further relax identification assumptions by adding factory-specific linear time trends to the model (i.e. introducing $j=5,722$ linear time trend predictors corresponding to each 
factory in the panel).

$$
Y_{i t}=\eta_{i}+\delta_{t}+\beta_{1} \text { Compliance }_{i t}+\sum_{i=1}^{j} \gamma_{i} \operatorname{Trend}_{i}+\varepsilon_{i t}
$$

[Table 2 here]

This model relaxes the parallel trends assumption in standard fixed effects models, as biases introduced by divergent linear trends across groups are captured by the factory-specific trends. To the extent that factory trends are correlated with any exogenous changes in factory compliance, they will erroneously bias estimates of the compliance toward zero. Columns 11 and 12 of Table 2 report point estimates that are positive and similar in magnitude to estimations from the main panel. However, these estimates are less precise, with $95 \%$ confidence intervals that include zero.

What is the economic significance of these effects? Table 3 reports effect magnitudes from the main panel estimates in both dollars and percent of annual order value. The models yield point estimates of increased order value ranging from USD 110,000 to 167,000 when an exporter transitions from noncompliant to compliant. This represents a $4 \%$ average increase in annual order value. These figures estimate annual purchasing using the midpoints of the annual purchasing bins provided by the sourcing agent. We also report linear probability models of exceeding various order thresholds in Appendix Table A5. These estimates find effects across several thresholds. For example, compliance is associated with a $4.8 \%$ increase in the probability of receiving more than $\$ 250,000$ in annual orders. These analyses show that effects are not driven by the high-uncertainty purchasing bins at the top of the distribution, nor are they driven by one idiosyncratic transition between order bins.

The magnitude of the within-factories effect is modest, and our data also confirm that many noncompliant factories continue to operate in global supply chains. Nonetheless we find evidence that importing firms in our sample prefer purchasing from export factories that comply with minimum labor and environmental standards.

$$
\text { [Table } 3 \text { here] }
$$

\section{Rewards and Penalties}

Two incentive mechanisms may explain the effects detected above. First, importers may increase purchasing when factories achieve compliance, rewarding factories for 
improvement. Second, they may reduce orders from factories that fall out of compliance, penalizing exporters whose standards decline.

We next divide factories into four groups within each two-year period: compliant in both years, falling out of compliance, moving into compliance, and noncompliant in both years. Comparing the first two groups reveals penalties for falling out of compliance. Comparing the latter two tells us whether there are rewards for achieving compliance. The initial results of this analysis are visualized in Figure 4. The top panel shows the raw results, and the bottom normalizes each year by the within-year mean order value, which helps to visualize results from 2011-2012 when overall orders increase for all groups. The figures suggest both negative incentives (penalties) and positive incentives (rewards) for complying with standards.

[Figure 4 here]

[Figure 5 here]

To reduce pre-treatment differences between factory groupings, we then use entropy balancing (Hainmueller 2012) to reweight the samples to achieve balanced moments on a variety of covariates (Appendix Table A6). In the reweighted samples, factories that transition and maintain their compliance status exhibit identical distributions of factory locations, product types, and initial-period order values. In 2010-2011 and 2011-2012, we also include the prior-year purchase value trend to control for divergent trends pre-dating the compliance transition. The graphical analysis in Figure 5 again shows relative declines for factories that fall out of compliance (compared to those that stay compliant) and relative gains for factories that achieve compliance (compared to those that stay noncompliant). Regression analyses of the unbalanced and balanced samples for each two-year panel are reported in Appendix Table A7. The effect of rebalancing on effect magnitude is mixed, but the evidence across all estimations and years is consistent with positive incentives for factories that achieve compliance and (weaker) penalties for those that fall out of compliance.

\section{Which industries exhibit compliance effects?}

The firms in this study include exporters in a variety of product categories. We use this variation to further test the plausibility of the results and explore possible mechanisms. One possible explanation of the patterns above is that importers use 
the compliance results to avoid the reputational risk of dealing with exporters engaged in socially harmful practices. Financial markets penalize firms for revelations of environmentally harmful activities, industrial accidents, and activist campaigns (Flammer 2013; King and Soule 2007). For consumer-facing firms like the retailers in our study, the perception that their suppliers exploit workers or cause environmental harm could have negative financial consequences.

Among the industries in this study, the global apparel industry has been more exposed to anti-sweatshop activism (Bartley and Child 2014). Other common product types like home furnishings (26\% of exporters) and cookware (14\%) have not been subject to similarly intense campaigns. If the mechanism generating our effects is the preference of certain importers to avoid non-compliant factories - rather than compliance-transitions being correlated with some unobservable quality of the product or factory - we expect effects to be strongest in industries targeted by activist campaigns. If our effects were driven instead by industries that are not subject to these campaigns, a different mechanism may be at work.

To explore this possibility, we estimate heterogeneous treatment effects by exporter industry. Table 4 shows that the only exporter industry in which effects are statistically different from zero is clothing. The effect magnitude of the binary compliance measure is roughly triple the next largest estimates, from toys and other products. This effect persists using both binary and continuous compliance indicators, and examining either the entire panel (columns 1 and 2) or the subset of factories that undergo compliance transitions (columns 3 and 4). This pattern is consistent with a mechanism in which importers subject to activist pressure prefer importing from compliant factories in order to reduce reputational risk 8

$$
\text { [Table } 4 \text { here] }
$$

\section{Discussion}

The importers in our study exhibit a preference for doing business with exporters that comply with basic labor and environmental standards. This pattern is inconsis-

\footnotetext{
${ }^{8}$ Additional analyses and robustness checks appear in the online appendix. These include relaxing the linearity assumption of performance controls, adding industry-specific trends in purchasing, adding controls for the length of the relationship between the sourcing agent and the manufacturers, and re-estimating effects in China and the rest of the world. The appendix also presents qualitative summaries of the common violations of key audit items.
} 
tent with either one or the other following assumptions underlying the race-to-thebottom logic in global trade: (a) that compliance with basic labor and environmental standards makes exporters less competitive in price, quality, or delivery, or (b) that importers are unwilling to pay more to do business with compliant exporters. The absence of quantities and prices in our data do not allow us to tell which of these assumptions is inaccurate. We can say that they do not appear to simultaneously obtain in this sample of retailers and export manufacturers.

Our results suggest the presence of economic incentives for complying with social and environmental standards, whether these dynamics are driven by certain exporters proactively improving compliance or by the demands and market power of importers. Perhaps most surprising is that we observe these effects in emerging markets with poor enforcement of labor and associational rights. In this study, $91 \%$ of the export transactions (by value) originate from countries in the bottom two quartiles of fundamental labor rights, and $78 \%$ originate from countries in the bottom quartile in freedom of association rights (Appendix Table A2).

Understanding these dynamics in global supply chains is important to understanding the contemporary nexus of trade and social institutions. International trade is increasingly characterized by the prevalence of global supply (or value) chains (Porter 1986; Gereffi and Sturgeon 2005). In 2009, intermediate inputs traded within global supply chains accounted for $30 \%$ to $60 \%$ of national exports in G20 countries (OECD, WTO, and World Bank Group 2014). As a growing share of trade takes place within global supply chains, understanding their political economy is both theoretically relevant and of growing policy importance. The accompanying fragmentation and worldwide dispersion of production have created significant challenges for traditional forms of regulation of labor and environmental standards.

We estimate that achieving compliance with basic standards results in importers increasing annual order value by $4 \%$ on average (Table 3). Do these incentives for compliance imply that raising workplace standards is a good investment for emerging market exporters? The answer depends on whether the increase in order value results primarily from increased quantities or prices.9 $9^{9}$ If the compliance premium is due entirely to increased volume, and assuming momentarily that compliance is costless and other costs scale with volume, the factory's increase in

\footnotetext{
${ }^{9}$ In the following calculations, we assume that the $4 \%$ increase in buyer spend is uniform across all customers of the exporter, even though our data only captures this relationship for the group of importers represented by the sourcing company.
} 
operating profit is modest. Assuming a profit margin of $2 \%$, this volume premium would amount to an increase in gross profit by just $2 \% \times 4 \%=.08 \%$, before accounting for any costs of compliance. Yet if the $4 \%$ increase in value is a price premium, the same manufacturer's profit margin would increase from $2 \%$ to $6.1 \%$. Decomposing the compliance premium into quantities and prices is therefore crucial to understanding the implications for exporters.

To put these premiums in context, consider the costs of paying "living wages" to emerging market manufacturing workers. The Fair Wear Foundation (2014) examined garment manufacturers in China and Vietnam and estimated paying a living wage would require a $10 \%$ to $102 \%$ increase in mode sewing wages. In turn, these wage increases would raise unit prices paid by importers by $2 \%$ to $12 \%$ (2014: 18). A compliance premium of $4 \%$, if partially composed of a price premium, could therefore offset the cost of living wages in some exporters. The prospects for doing so appear greater in small exporters, where the compliance premium point estimate ranges from $7 \%-10 \%$ of average order size (Figure 6).

[Figure 6 here]

The foregoing analysis of the economic returns to compliance is necessarily somewhat speculative. Future work using more fine-grained data on prices and quantities may clarify these returns and their implications for investments in improved labor and environmental standards.

This study also suggests that transnational private regulation may be more effective than previously believed. The analysis suggests the presence of economic incentives for compliance in industries characterized by strong activist campaigns and private regulatory responses from industry. This finding complements new survey research on the willingness of developing country producers to incur compliance costs to integrate into global supply chains (Malesky and Mosley 2016). However, it also raises new questions about private regulation in global supply chains. Are the incentives detected here sufficient to support desired investments in worker wages, factory safety, and environmental impact mitigation? What is the appropriate compliance premium in both price and volume to justify these investments? Future research may answer these questions and provide practical recommendations on the design of multinational sourcing practices that support improved labor and environmental standards.

This study is the first to estimate the relationship between exporter social compliance and importer behavior in a large international sample of factories, but 
there are important limitations to keep in mind. First, we cannot tell whether we observe these patterns because (a) certain exporters can achieve compliance with minimum standards without raising prices, or (b) certain importers are willing to pay more to do business with compliant exporters. We can only infer that both are not simultaneously true. Second, because these data come from one sourcing agent, they do not account for the entire portfolio of customers for each exporting factory. These unobserved customers may be indifferent to social compliance or even reduce orders when factories achieve compliance. In the latter case, the estimated effect of compliance may represent a reallocation of business away from importers that are insensitive to social compliance and toward importers in our study who are sensitive to compliance. In this case, it seems likely that the reallocation occurs because exporters perceive economic benefits to doing business with reputation-sensitive importers, such as better prices or opportunities for growth. Addressing these possibilities awaits future research using the administrative records of exporting factories, rather than their customers. Third, the patterns observed here pertain to trade between retailers in western countries and exporters of light manufactures in emerging markets. The study has little to say about incentives for compliance in other global supply chains, such as those for electronics, minerals, or agricultural products, or where both trading partners are based in developing or middle-income countries.

Although within-factories estimates from panel data offer improved causal credibility over cross-sectional analyses, these models may also obscure alternative causal pathways between compliance to importer behavior. If exporters build durable reputations as either socially compliant or noncompliant, importers familiar with these reputations may discount information transmitted through compliance audits, reasoning that some year-on-year variation reflects measurement error rather than meaningful improvement or declines. Consistent with this supposition, we find smaller magnitude effects of compliance on factories that have longer business relationships with the sourcing agent, although we cannot reject the hypothesis that these effects are identical (Appendix Table A12). Panel fixed-effects models remove any static effects from durable factory reputations. This reduces bias insofar as these reputations reflect issues other than social compliance and are correlated with compliance status in cross-section. However, if reputations for social responsibility are themselves important drivers of customer orders, factory fixed-effects would mask these relationships.

Keeping these limitations in mind, this research contributes new findings 
to debates about a race to the bottom in global supply chains (Rodrik 1997; Vogel 2005; Mosley 2010; Locke 2013; Weil 2014). The results suggest the possibility of a "high road" to growth for small exporters in emerging markets. Social upgrading - achieving compliance with international labor, health, and environmental standards - may offer an opportunity for these enterprises to pursue more lucrative opportunities in the global economy. Yet it is also clear that whatever market incentives exist for such social upgrading, they are insufficient to bring the majority of exporters in this study into compliance. Although the net impact of activist campaigns and resulting private regulatory activities may be positive, this model still falls far short of guaranteeing basic rights for the millions of workers employed in global supply chains. 


\section{References}

Amengual, Matthew. 2010. "Complementary Labor Regulation: The Uncoordinated Combination of State and Private Regulators in the Dominican Republic." World Development 38(3):405-414.

Amengual, Matthew and Laura Chirot. 2016. "Reinforcing the State: Transnational and State Labor Regulation in Indonesia." Industrial and Labor Relations Review p. doi: 10.1177/0019793916654927.

Anner, Mark. 2012. "Corporate Social Responsibility and Freedom of Association Rights The Precarious Quest for Legitimacy and Control in Global Supply Chains." Politics \& Society 40(4):609-644.

Ansell, Ben W. 2008. "Traders, teachers, and tyrants: democracy, globalization, and public investment in education." International Organization 62(2):289-322.

Barrientos, Stephanie. 2013. "Corporate Purchasing Practices in Global Production Networks: A Socially Contested Terrain." Geoforum 44:44-51.

Bartley, Tim. 2007. "Institutional Emergence in an Era of Globalization: The Rise of Transnational Private Regulation of Labor and Environmental Conditions." American Journal of Sociology 113(2):297-351.

Bartley, Tim and Curtis Child. 2014. "Shaming the corporation: The social production of targets and the anti-sweatshop movement." American Sociological Review 79(4):653-679.

Bloom, Nicholas, Benn Eifert, Aprajit Mahajan, David McKenzie and John Roberts. 2013. "Does Management Matter? Evidence from India." The Quarterly Journal of Economics 128(1):1-51.

Cao, Xun, Brian Greenhill and Aseem Prakash. 2013. "Where is the tipping point? Bilateral trade and the diffusion of human rights." British Journal of Political Science 43(01):133-156.

Chan, Anita. 2003. "Racing to the bottom: international trade without a social clause." Third World Quarterly 24(6):1011-1028.

Chan, Jenny, Ngai Pun and Mark Selden. 2013. "The politics of global production: Apple, Foxconn and China's new working class." New Technology, Work and Employment 28(2):100-115.

Coslovsky, Salo V and Richard Locke. 2013. "Parallel Paths to Enforcement: Private Compliance, Public Regulation, and Labor Standards in the Brazilian Sugar Sector." Politics 8 Society 41(4):497-526.

De Janvry, Alain, Craig McIntosh and Elisabeth Sadoulet. 2015. "Fair trade and free entry: can a disequilibrium market serve as a development tool?" Review of Economics and Statistics 97(3):567-573.

Distelhorst, Greg, Richard M Locke, Timea Pal and Hiram M Samel. 2015. "Production Goes Global, Compliance Stays Local: Private regulation in the global electronics industry." Regulation \& Governance 9:224-242.

Drezner, Daniel W. 2001. "Globalization and policy convergence." International Studies Review 3(1):53-78.

Elliott, Kimberly A. and Richard B. Freeman. 2003. Can Labor Standards Improve 
Under Globalization? Peterson Institute.

Engels, Friedrich. 1888. On the Question of Free Trade: Preface for the 1888 English edition pamphlet.

URL: https://www.marxists.org/archive/marx/works/1888/free-trade/index.htm

Fair Wear Foundation. 2014. "Living Wage Engineering.".

URL: $h t t p: / / g o o . g l / p 6 Z V b 0$

Flammer, Caroline. 2013. "Corporate Social Responsibility and Shareholder Reaction: The Environmental Awareness of Investors." Academy of Management Journal 56(3):758-781.

Fung, Archon, Dara O'Rourke and Charles F. Sabel. 2001. Can We Put an End to Sweatshops? A New Democracy Forum on Raising Global Labor Standards. Beacon Press.

Garrett, Geoffrey. 1998. "Global markets and national politics: collision course or virtuous circle?" International Organization 52(4):787-824.

Gereffi, Gary, Humphrey John and Timothy Sturgeon. 2005. "The governance of global value chains." Review of International Political Economy 12(1):78-104.

Greenhill, Brian, Layna Mosley and Aseem Prakash. 2009. "Trade-based diffusion of labor rights: A panel study, 1986-2002." American Political Science Review 103(04):669-690.

Hafner-Burton, Emilie M. 2005. "Trading human rights: How preferential trade agreements influence government repression." International Organization 59(3):593-629.

Hainmueller, Jens. 2012. "Entropy Balancing for Causal Effects: A Multivariate Reweighting Method to Produce Balanced Samples in Observational Studies." Political Analysis 20(1):25-46.

Hainmueller, Jens, Michael J Hiscox and Sandra Sequeira. 2015. "Consumer demand for Fair Trade: evidence from a multistore field experiment." Review of Economics and Statistics 97(2):242-256.

Harrison, Ann and Jason Scorse. 2010. "Multinationals and Anti-Sweatshop Activism." The American Economic Review 100(1):247-273.

King, Brayden G and Sarah A Soule. 2007. "Social movements as extra-institutional entrepreneurs: The effect of protests on stock price returns." Administrative Science Quarterly 52(3):413-442.

Kucera, David. 2001. "The Effects of Core Workers Rights on Labour Costs and Foreign Direct Investment: Evaluating the Conventional Wisdom." International Labour Organization .

URL: https://goo.gl/dYalZC

Levi, Margaret, Christopher Adolph, Daniel Berliner, Aaron Erlich, Anne Greenleaf, Milli Lake and Jennifer Noveck. 2013. "Aligning Rights and Interests: Why, When and How to Uphold Labor Standards." The World Bank: Background Paper For The World Development Report 2013.

URL: https://goo.gl/rsxNJu

Locke, Richard M. 2013. The Promise and Limits of Private Power: Promoting Labor Standards in a Global Economy. Cambridge University Press. 
Locke, Richard M., Fei Qin and Alberto Brause. 2007. "Does Monitoring Improve Labor Standards? Lessons from Nike." Industrial and Labor Relations Review 61(1):3-31.

Locke, Richard M., Matthew Amengual and Akshay Mangla. 2009. "Virtue out of Necessity? Compliance, Commitment, and the Improvement of Labor Conditions in Global Supply Chains." Politics \& Society 37(3):319.

Lund-Thomsen, Peter and Adam Lindgreen. 2014. "Corporate social responsibility in global value chains: Where are we now and where are we going?" Journal of Business Ethics 123(1):11-22.

Malesky, Edmund and Layna Mosley. 2016. "Chains of Love? Global Production, Developing Country Firms and the Diffusion of Labor Standards." Niehaus Center, Princeton University: Workshop on The Politics of Multinational Firms, Governments, and Global Production Networks .

Mattli, Walter and Tim Büthe. 2005. "Accountability in Accounting? The Politics of Private Rule-Making in the Public Interest." Governance 18(3):399-429.

Mayer, Frederick and Gary Gereffi. 2010. "Regulation and economic globalization: Prospects and limits of private governance." Business and Politics 12(3).

Milewicz, Karolina M., James Hollway, Claire Peacock and Duncan Snidal. 2016. "Beyond trade: the expanding scope of the nontrade agenda in trade agreements." Journal of Conflict Resolution p. doi: 10.1177/0022002716662687.

Mosley, Layna. 2010. Labor Rights and Multinational Production. Cambridge University Press.

Mosley, Layna and Saika Uno. 2007. "Racing to the bottom or climbing to the top? Economic globalization and collective labor rights." Comparative Political Studies 40(8):923-948.

Nadvi, Khalid and Gale Raj-Reichert. 2015. "Governing health and safety at lower tiers of the computer industry global value chain." Regulation \& Governance 9:243258.

Neumayer, Eric and Indra De Soysa. 2006. "Globalization and the right to free association and collective bargaining: An empirical analysis." World Development $34(1): 31-49$.

OECD, WTO, and World Bank Group. 2014. Global Value Chains: Challenges, Opportunities and Implications for Policy.

URL: https://www.oecd.org/tad/gvc_report_g20_july_2014.pdf

Oka, Chikako. 2012. "Does Better Labour Standard Compliance Pay? Linking Labour Standard Compliance and Supplier Competitiveness." Better Work Discussion Paper Series 5.

URL: https://goo.gl/gZtRFry

O'Rourke, Dara. 2003. "Outsourcing Regulation: Analyzing Nongovernmental Systems of Labor Standards and Monitoring." Policy Studies Journal 31(1):1-29.

Porter, Michael E. 1986. "Changing patterns of international competition." California Management Review 28(2):9-40.

Rickard, Stephanie J. 2012. "Welfare versus subsidies: Governmental spending decisions in an era of globalization." The Journal of Politics 74(04):1171-1183. 
Rodrik, Dani. 1997. Has Globalization Gone Too Far? Peterson Institute.

Rodrik, Dani. 1998. "Why do more open economies have bigger governments?" Journal of Political Economy 106(5):997-1032.

Rudra, Nita. 2005. "Are workers in the developing world winners or losers in the current era of globalization?" Studies in Comparative International Development 40(3):29-64.

Rudra, Nita. 2008. Who Really Gets Hurt? Globalization and the Race to the Bottom in Developing Countries. Cambridge University Press.

Ruwanpura, Kanchana N and Neil Wrigley. 2011. "The Costs of Compliance? Views of Sri Lankan Apparel Manufacturers in Times of Global Economic Crisis." Journal of Economic Geography 11(6):1031-1049.

Seidman, Gay. 2007. Beyond the Boycott: Labor Rights, Human Rights, and Transnational Activism. Russell Sage Foundation Publications.

Toffel, Michael W, Jodi L Short and Melissa Ouellet. 2015. "Codes in context: How states, markets, and civil society shape adherence to global labor standards." Regulation \& Governance 9(3):205-223.

Vadlamannati, Krishna Chaitanya. 2015. "Rewards of (Dis) Integration Economic, Social, and Political Globalization and Freedom of Association and Collective Bargaining Rights of Workers in Developing Countries." Industrial and Labor Relations Review 68(1):3-27.

Vogel, David. 1995. Trading up: Consumer and environmental regulation in a global economy. Harvard University Press.

Vogel, David. 2005. The market for virtue: The potential and limits of corporate social responsibility. Brookings Institution Press.

Vogel, David. 2008. "Private Global Business Regulation." Annual Review of Political Science 11:261-282.

Weil, David. 2014. The Fissured Workplace: Why Work Became So Bad for So Many and What Can Be Done to Improve It. Harvard University Press.

Workers Rights Consortium. 2014. Stealing from the Poor: Wage Theft in the Haitian Apparel Industry. Research Report.

URL: https://goo.gl/odBHJY 
Figure 1: Hypothesized mechanisms linking trade and social institutions

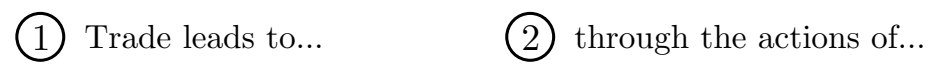

\begin{tabular}{|c|c|c|}
\hline & States & Firms \\
\hline $\begin{array}{l}\text { Race to the bottom } \\
\text { Downward harmonization of standards }\end{array}$ & $\begin{array}{l}\text { States compete by } \\
\text { reducing regulatory } \\
\text { burdens }\end{array}$ & $\begin{array}{l}\text { Exporters compete by } \\
\text { reducing compliance } \\
\text { with standards }\end{array}$ \\
\hline \multirow[t]{3}{*}{$\begin{array}{l}\text { "California effects" } \\
\text { Upward harmonization of standards }\end{array}$} & $\begin{array}{l}\text { States negotiate common } \\
\text { standards; powerful } \\
\text { parties set them }\end{array}$ & $\begin{array}{l}\text { Importers prefer } \\
\text { buying from higher- } \\
\text { standards exporters }\end{array}$ \\
\hline & $\begin{array}{l}\text { Previous empirical research: } \\
\text { National policies set by states } \\
\text { Vogel 1995, Rodrik } 1997, \\
\text { Kucera 2001, Rudra } 2002, \\
\text { 2008, Greenhill, Mosley \& } \\
\text { Prakash 2009, Mosley 2010, } \\
\text { Vadlamannati 2015. }\end{array}$ & $\begin{array}{l}\text { This study focuses on } \\
\text { firm-level mechanisms }\end{array}$ \\
\hline & \multicolumn{2}{|c|}{$\begin{array}{l}\text { Previous empirical research: } \\
\text { National outcomes (e.g. violations) shaped by both states and firms } \\
\text { Kucera 2001, Neumayer \& de Soysa 2006, Mosley \& Uno 2007, } \\
\text { Greenhill, Mosley \& Prakash 2009, Mosley 2010, Vadlamannati } 2015 .\end{array}$} \\
\hline
\end{tabular}


Figure 2: Importers are primarily retailers in advanced economies

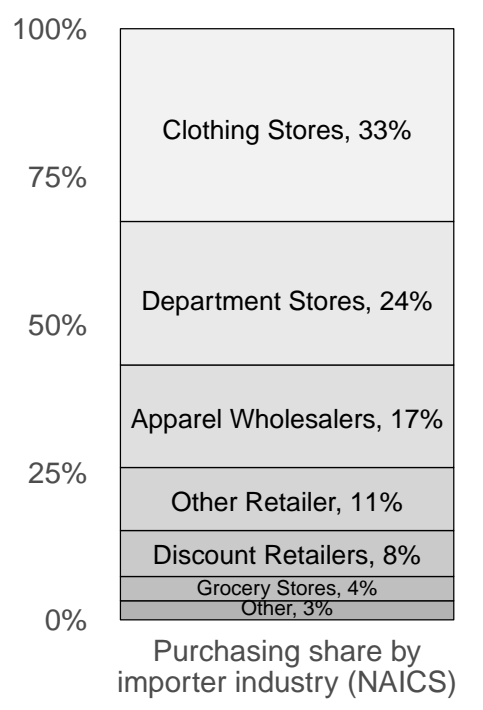

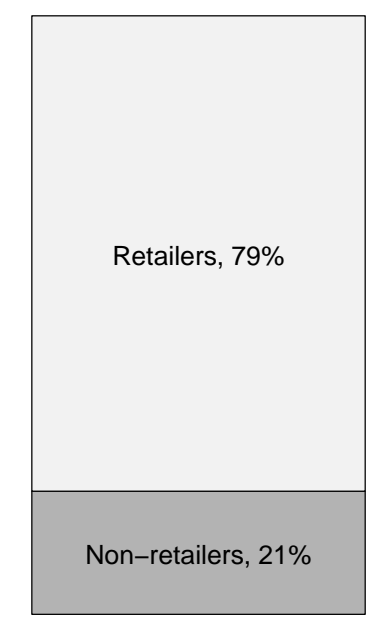

Purchasing share of retailers

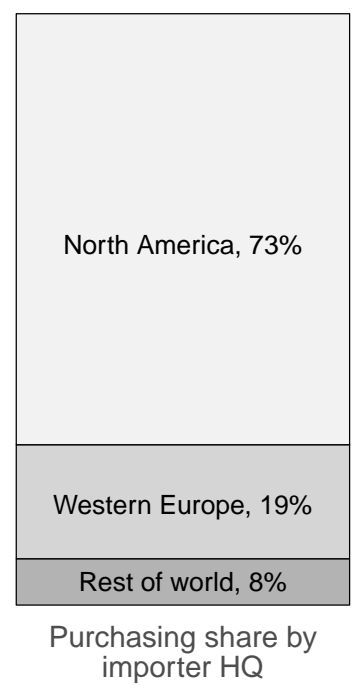

Notes. Estimated distribution of importer industries and headquarter locations in sourcing agent data. Figure based on the top 200 importers in the sample, who account for an estimated $93 \%$ of import volume over 2009-2012.

Figure 3: Importers purchase from countries with poor labor rights

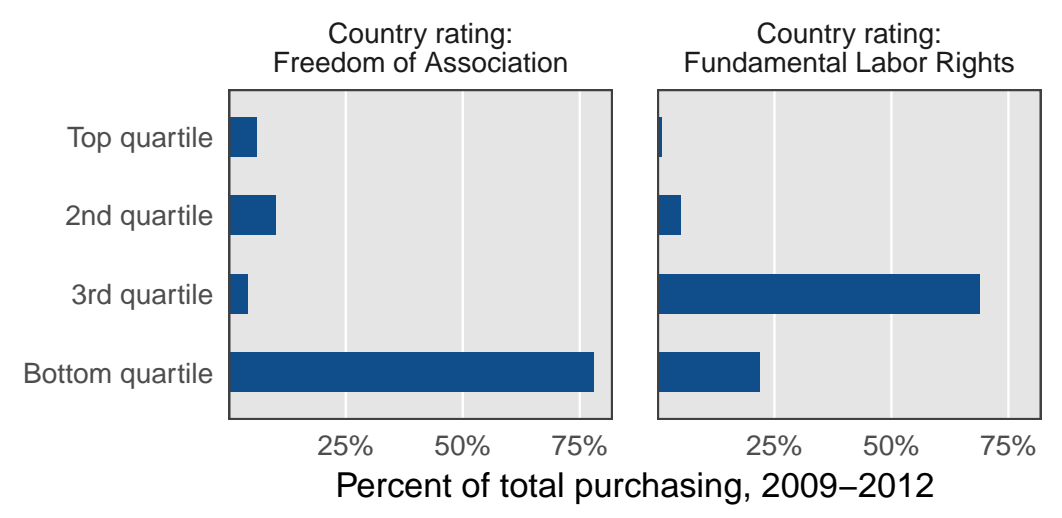

Notes. Distribution of purchasing value by exporting country in sourcing agent data. Freedom of association and labor rights country ratings from the World Justice Project, 2012-2013. Detailed purchasing by country reported in Appendix Table A2. 
Figure 4: Order values by compliance trajectory, two-year panels
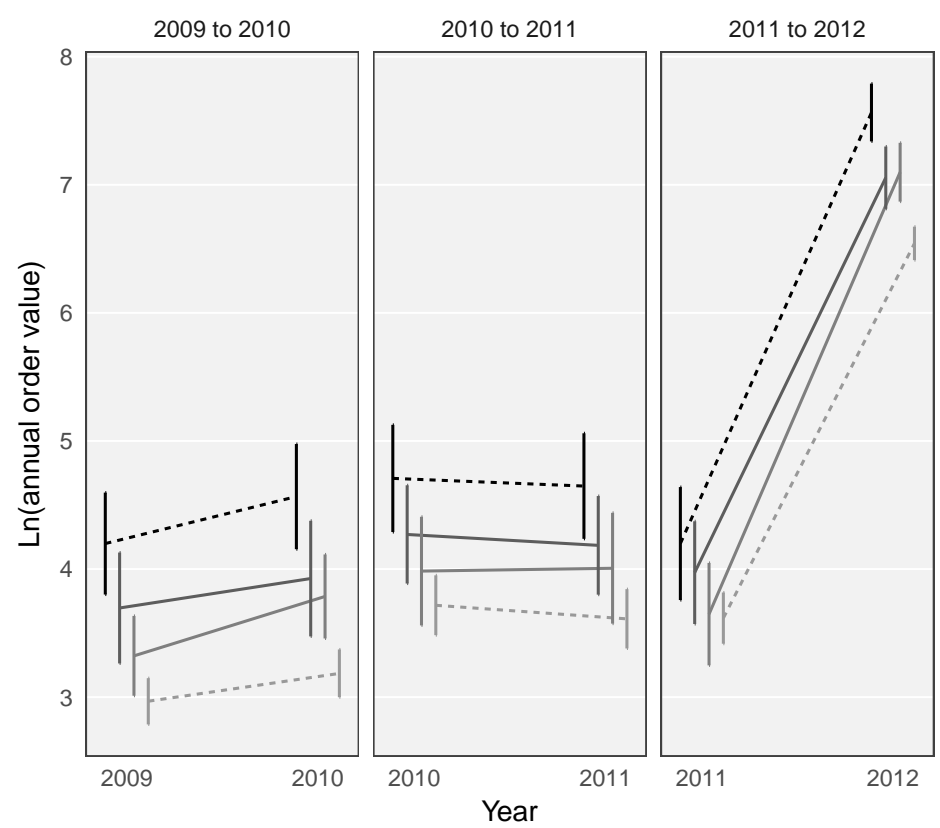

\section{Factory group}

- - Compliant both years

— Falls out of compliance

- Moves into compliance

- - Noncompliant both years
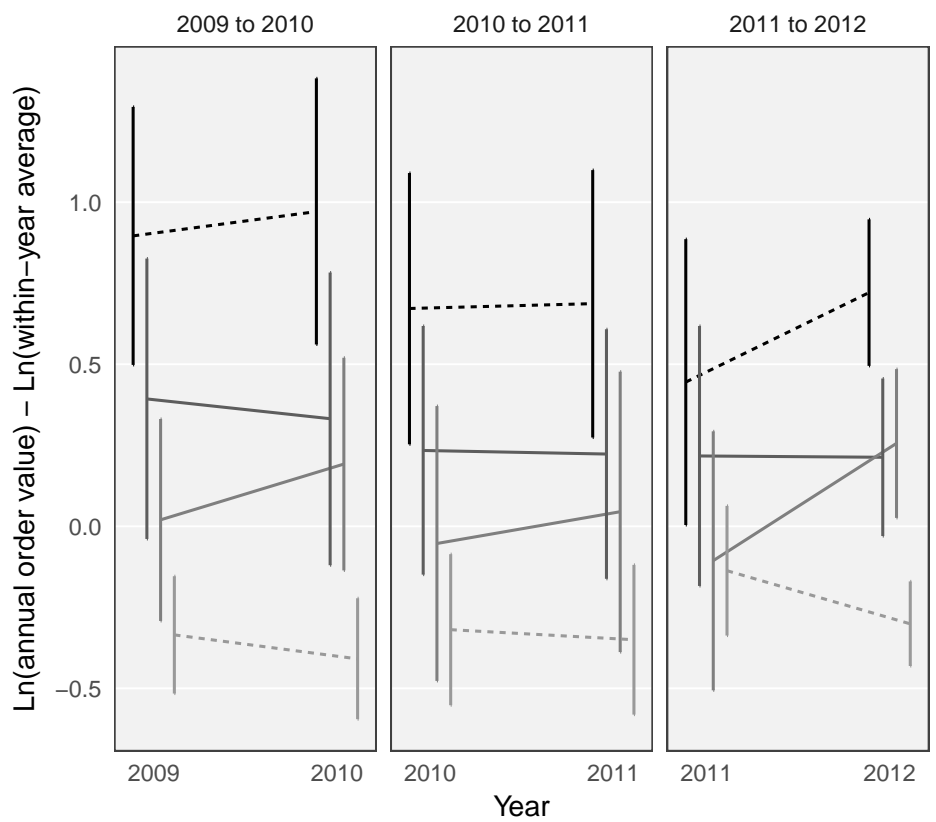

Factory group

- - Compliant both years

- Falls out of compliance

— Moves into compliance

- - Noncompliant both years

Notes. Two-year panels of factory mean order value (logged thousand USD), sorted by factory compliance trajectories. From top to bottom, factories are either (a) compliant in both years, (b) compliant, then noncompliant, (c) noncompliant, then compliant, and (d) noncompliant in both years. Bottom panel subtracts within-year order value means to aid interpretation. Note that annual means vary by facet because each analysis includes only factories with observations in both years. Error bars show $95 \%$ confidence intervals. 
Figure 5: Order values by compliance trajectory (entropy-balanced subsamples)
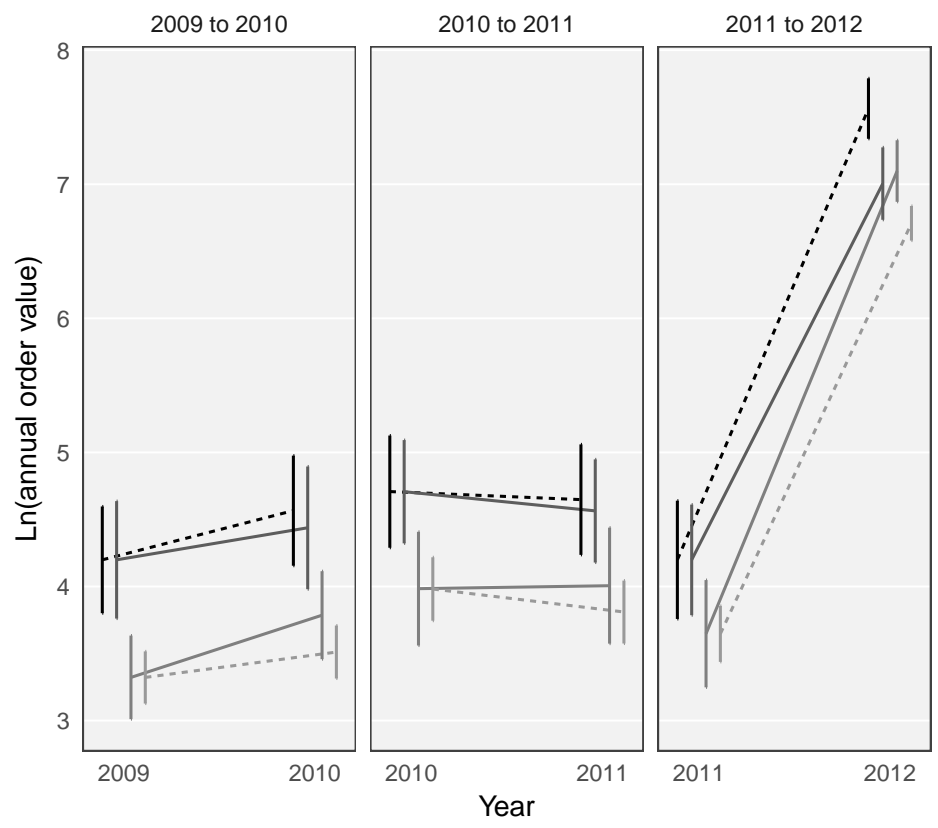

\section{Factory group \\ - - Compliant both years \\ - Falls out of compliance \\ - Moves into compliance \\ - - Noncompliant both years}

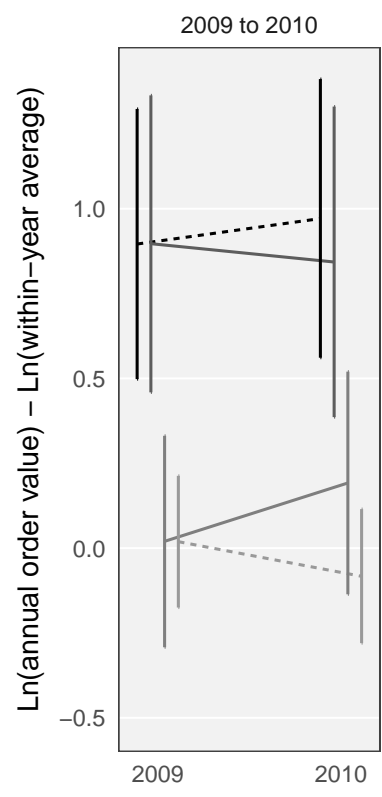

2010 to 2011

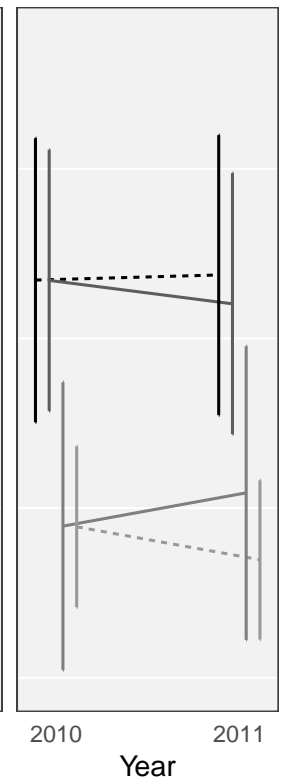

2011 to 2012

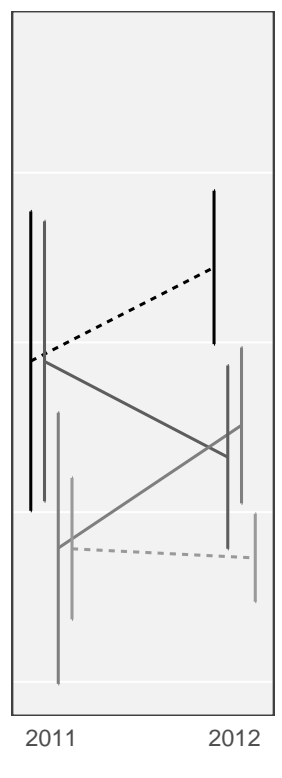

Factory group

- - Compliant both years

— Falls out of compliance

— Moves into compliance

- - Noncompliant both years

Notes. Adjusting the analysis in Figure 4 using entropy balancing (Hainmueller 2012). Each factory subsample is balanced on first-year order value, prior-year order value trend, distribution of factory locations, and distribution of factory product-types. Note that pre-trends are not available for balancing in 2009-2010 because we have no prior-year order value to establish trends. See Appendix Table A7 for regression estimates and Appendix Table A6 for balance tables. Error bars show $95 \%$ confidence intervals. 
Figure 6: Effects of compliance by factory size

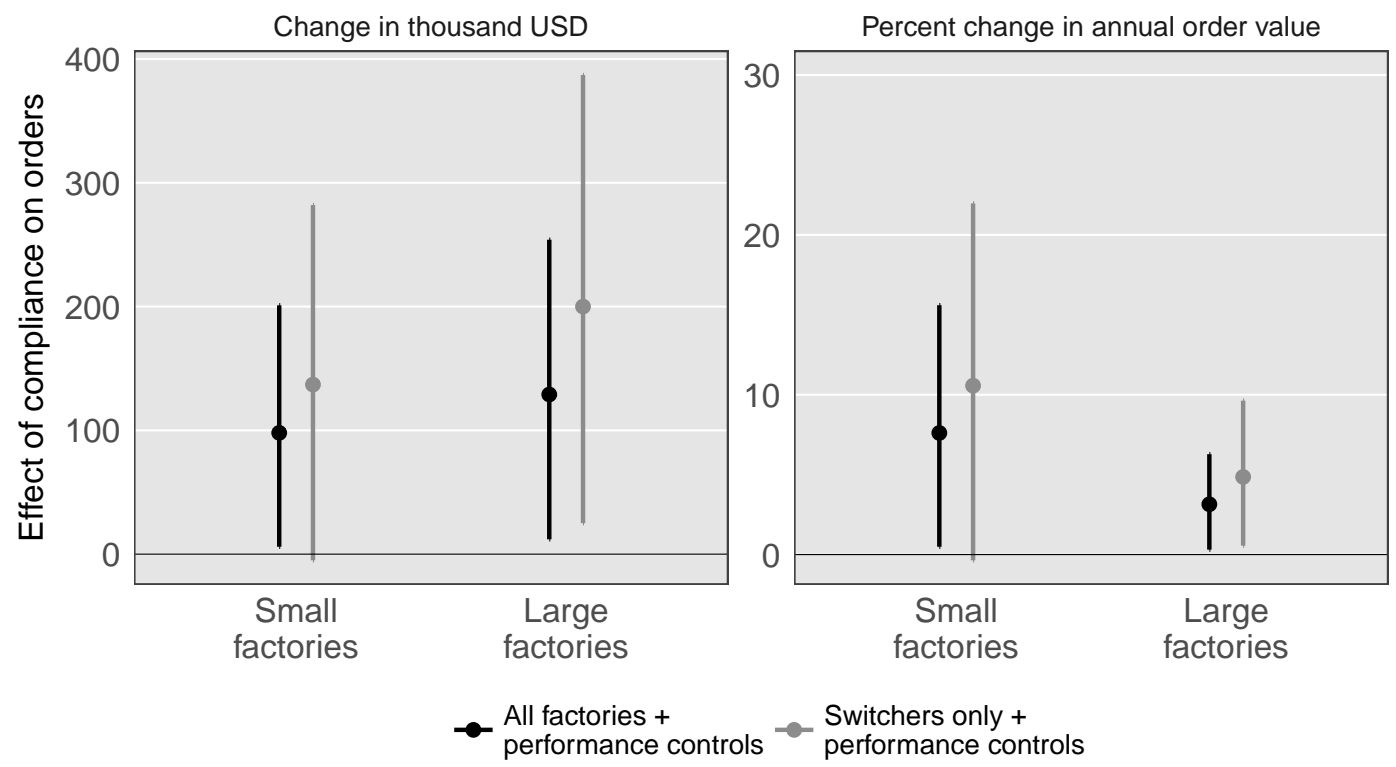

Notes. Effects of compliance on order value by factory size, estimated in panel models reported in the appendix. Factories are divided into two equally-sized pools by average annual employment: small (4-293 employees) and large (293-11,105 employees). Error bars show $95 \%$ confidence intervals. Results also reported in Appendix Table A11. 
Table 1: Cross-sectional comparison of compliant and noncompliant factories (2012)

\begin{tabular}{lcrrrr}
\hline \hline & Compliant & Noncompliant & Difference & SE & pval \\
\hline Annual orders & & & & & \\
Order value (thou. USD) & $\$ 4,116$ & $\$ 2,504$ & $-1,612$ & 213 & .000 \\
Log order value & 7.11 & 6.26 & -.85 & .07 & .000 \\
\hline Factory location (binary indicators) & & & & \\
China & .55 & .63 & .08 & .02 & .000 \\
India & .11 & .08 & -.03 & .01 & .021 \\
Bangladesh & .01 & .08 & .07 & .01 & .000 \\
Indonesia & .04 & .05 & .01 & .01 & .076 \\
Vietnam & .07 & .04 & -.03 & .01 & .001 \\
Thailand & .02 & .03 & 0 & .01 & .432 \\
Turkey & .02 & .02 & 0 & 0 & .647 \\
Philippines & .02 & .01 & -.01 & 0 & .185 \\
Taiwan & .04 & .01 & -.02 & .01 & .000 \\
Cambodia & .01 & .01 & 0 & 0 & .506 \\
Pakistan & .01 & .01 & 0 & 0 & .613 \\
Other countries & .11 & .03 & -.08 & .01 & .000 \\
\hline Products (binary indicators) & & & & & \\
Clothing & .59 & .47 & -.12 & .02 & .000 \\
Furniture \& homedecor & .20 & .20 & .00 & .01 & .862 \\
Toys & .18 & .17 & -.01 & .01 & .598 \\
Cookware & .10 & .10 & -.01 & .01 & .393 \\
Others & .15 & .24 & .08 & .01 & .000 \\
\hline Factory size \& performance & & & & & \\
Employees & 677 & 581 & -96 & 36 & .008 \\
On-time delivery (\%) & .75 & .71 & -.04 & .01 & .000 \\
Quality inspection (\%) & .94 & .91 & -.03 & 0 & .000 \\
\hline Total factories & 981 & 3,328 & & & \\
Share of sample & $21 \%$ & $79 \%$ & & & \\
\hline
\end{tabular}

Notes. Standard errors and p-values from two-sided t-tests assuming unequal variances. Note that there are more factories in this cross-sectional 2012 sample than the subsequent panel analysis, as the panel analysis excludes factories that appear only once in the four-year panel. For regression analysis of order value using these variables as predictors, see Appendix Table A3. 
Table 2: Panel estimates of effect of compliance on order value (logged USD, thousands)

\begin{tabular}{|c|c|c|c|c|c|c|c|c|c|c|c|c|}
\hline & \multicolumn{4}{|c|}{$\begin{array}{c}\text { Main panel: } \\
\text { Factories with performance data }\end{array}$} & \multicolumn{4}{|c|}{$\begin{array}{c}\text { Main panel subsample: } \\
\text { Within-factory compl. transitions }\end{array}$} & \multicolumn{4}{|c|}{ All factories } \\
\hline & $(1)$ & $(2)$ & $(3)$ & $(4)$ & $(5)$ & (6) & $(7)$ & $(8)$ & (9) & (10) & (11) & $(12)$ \\
\hline $\begin{array}{l}\text { Compliance } \\
\text { (binary) }\end{array}$ & $\begin{array}{l}.143 \\
(.048)\end{array}$ & $\begin{array}{l}.143 \\
(.048)\end{array}$ & & & $\begin{array}{l}.142 \\
(.048)\end{array}$ & $\begin{array}{l}.139 \\
(.048)\end{array}$ & & & $\begin{array}{l}.256 \\
(.055)\end{array}$ & & $\begin{array}{l}.126 \\
(.081)\end{array}$ & \\
\hline $\begin{array}{l}\text { Compliance } \\
\text { (A-D) }\end{array}$ & & & $\begin{array}{l}.093 \\
(.035)\end{array}$ & $\begin{array}{l}.093 \\
(.034)\end{array}$ & & & $\begin{array}{l}.095 \\
(.036)\end{array}$ & $\begin{array}{l}.093 \\
(.036)\end{array}$ & & $\begin{array}{l}.161 \\
(.039)\end{array}$ & & $\begin{array}{l}.106 \\
(.059)\end{array}$ \\
\hline On-time delivery & & $\begin{array}{l}-.072 \\
(.113)\end{array}$ & & $\begin{array}{l}-.074 \\
(.113)\end{array}$ & & $\begin{array}{l}-.208 \\
(.191)\end{array}$ & & $\begin{array}{l}-.21 \\
(.19)\end{array}$ & & & & \\
\hline Quality inspection & & $\begin{array}{l}-.087 \\
-0.19\end{array}$ & & $\begin{array}{l}-.089 \\
-0.19\end{array}$ & & $\begin{array}{l}-.375 \\
(.344)\end{array}$ & & $\begin{array}{l}-.376 \\
(.343)\end{array}$ & & & & \\
\hline 2010 fixed effect & $\begin{array}{l}.016 \\
(.051)\end{array}$ & $\begin{array}{l}.015 \\
(.051)\end{array}$ & $\begin{array}{l}.018 \\
(.051)\end{array}$ & $\begin{array}{l}.017 \\
(.051)\end{array}$ & $\begin{array}{l}.197 \\
(.069)\end{array}$ & $\begin{array}{l}.194 \\
(.069)\end{array}$ & $\begin{array}{l}.201 \\
(.069)\end{array}$ & $\begin{array}{l}.198 \\
(.069)\end{array}$ & $\begin{array}{l}.093 \\
(.036)\end{array}$ & $\begin{array}{l}.098 \\
(.035)\end{array}$ & $\begin{array}{l}1.69 \\
(.059)\end{array}$ & $\begin{array}{l}1.69 \\
(.059)\end{array}$ \\
\hline 2011 fixed effect & $\begin{array}{l}-.105 \\
(.059)\end{array}$ & $\begin{array}{l}-.105 \\
(.058)\end{array}$ & $\begin{array}{l}-.106 \\
(.059)\end{array}$ & $\begin{array}{l}-.105 \\
(.058)\end{array}$ & $\begin{array}{l}.087 \\
(.081)\end{array}$ & $\begin{array}{l}.091 \\
(.081)\end{array}$ & $\begin{array}{l}.086 \\
(.081)\end{array}$ & $\begin{array}{l}.091 \\
(.081)\end{array}$ & $\begin{array}{l}.284 \\
(.040)\end{array}$ & $\begin{array}{l}.286 \\
(.040)\end{array}$ & $\begin{array}{l}3.15 \\
(.071)\end{array}$ & $\begin{array}{l}3.15 \\
(.071)\end{array}$ \\
\hline 2012 fixed effect & $\begin{array}{l}-.129 \\
(.062) \\
\end{array}$ & $\begin{array}{l}-.129 \\
(.062) \\
\end{array}$ & $\begin{array}{l}-.129 \\
(.062) \\
\end{array}$ & $\begin{array}{l}-.129 \\
(.062) \\
\end{array}$ & $\begin{array}{l}.140 \\
(.084) \\
\end{array}$ & $\begin{array}{l}.145 \\
(.083) \\
\end{array}$ & $\begin{array}{l}.143 \\
(.084) \\
\end{array}$ & $\begin{array}{l}.147 \\
(.083) \\
\end{array}$ & $\begin{array}{l}3.45 \\
(.070) \\
\end{array}$ & $\begin{array}{c}3.46 \\
(.070) \\
\end{array}$ & $\begin{array}{l}7.52 \\
(.015) \\
\end{array}$ & $\begin{array}{r}7.52 \\
(.015) \\
\end{array}$ \\
\hline $\begin{array}{l}\text { Factory fixed effects } \\
\text { Factory time trends }\end{array}$ & $\checkmark$ & $\checkmark$ & $\checkmark$ & $\checkmark$ & $\checkmark$ & $\checkmark$ & $\checkmark$ & $\checkmark$ & $\checkmark$ & $\checkmark$ & $\begin{array}{l}\checkmark \\
\checkmark\end{array}$ & $\begin{array}{l}\checkmark \\
\checkmark\end{array}$ \\
\hline Constant & $\begin{array}{c}6.6 \\
(.043)\end{array}$ & $\begin{array}{c}6.8 \\
(.193)\end{array}$ & $\begin{array}{c}6.5 \\
(.062)\end{array}$ & $\begin{array}{c}6.7 \\
(.196)\end{array}$ & $\begin{array}{l}6.9 \\
(.057)\end{array}$ & $\begin{array}{l}7.4 \\
(.359) \\
\end{array}$ & $\begin{array}{c}6.8 \\
(.077)\end{array}$ & $\begin{array}{l}7.3 \\
(.360)\end{array}$ & $\begin{array}{c}2.8 \\
(.033)\end{array}$ & $\begin{array}{c}2.6 \\
(.06)\end{array}$ & $\begin{array}{c}3.8 \\
(.068)\end{array}$ & $\begin{array}{c}3.7 \\
(.097) \\
\end{array}$ \\
\hline Observations & 6,915 & 6,915 & 6,915 & 6,915 & 3,235 & 3,235 & 3,235 & 3,235 & 15,956 & 15,956 & 15,956 & 15,956 \\
\hline R-squared & .005 & .005 & .004 & .005 & .008 & .010 & .007 & .009 & .366 & .365 & .799 & .799 \\
\hline Factories & 2,447 & 2,447 & 2,447 & 2,447 & 1,028 & 1,028 & 1,028 & 1,028 & 5,722 & 5,722 & 5,722 & 5,722 \\
\hline
\end{tabular}

Notes. OLS panel fixed effects regression from 2009 to 2012. Models (1) - (4) fit using main panel of factories with performance data (Table A1). Models (5) - (8) fit on subsample of the main panel that undergoes a transition in compliance status over the period studied. Models (9) - (12) fit on all factories that appear at least twice in the panel, with 5,722 linear time-trends corresponding to each factory in Models (11) and (12). Standard errors clustered by factory in parentheses. 
Table 3: Effects magnitudes from panel estimates

\begin{tabular}{lrrrr}
\hline \hline & Model 1 & Model 2 & Model 5 & Model 6 \\
\hline $\begin{array}{l}\text { Point estimate } \\
\text { (thousand USD) }\end{array}$ & $\$ 111$ & $\$ 110$ & $\$ 167$ & $\$ 164$ \\
95\% CI Lower & $\$ 31$ & $\$ 32$ & $\$ 55$ & $\$ 52$ \\
$95 \%$ CI Upper & $\$ 191$ & $\$ 190$ & $\$ 282$ & $\$ 278$ \\
\hline $\begin{array}{l}\text { Point estimate } \\
\text { (\% of mean order value) }\end{array}$ & $4.21 \%$ & $4.19 \%$ & $4.42 \%$ & $4.36 \%$ \\
$95 \%$ CI Lower & $1.14 \%$ & $1.15 \%$ & $1.40 \%$ & $1.35 \%$ \\
$95 \%$ CI Upper & $7.39 \%$ & $7.36 \%$ & $7.53 \%$ & $7.48 \%$ \\
\hline
\end{tabular}

Notes. Average effects of moving from non-compliant to compliant on annual order value, calculated from panel models estimated in Table 2. Percentages based on mean order value among noncompliant factories in sample. Distributions of effect magnitudes obtained through bootstrapping $(B=1,000)$. 
Table 4: Effects of compliance by exporter industry (logged USD, thousands)

\begin{tabular}{|c|c|c|c|c|}
\hline & \multicolumn{2}{|c|}{$\begin{array}{l}\text { Main panel with } \\
\text { performance data }\end{array}$} & \multicolumn{2}{|c|}{$\begin{array}{c}\text { Subsample: } \\
\text { compl. transitions }\end{array}$} \\
\hline & $(1)$ & $(2)$ & $(3)$ & $(4)$ \\
\hline $\begin{aligned} \text { Clothing } & \times \text { Compliance (binary) } \\
& \times \text { Compliance }(\mathrm{A}-\mathrm{D})\end{aligned}$ & $\begin{array}{l}.190 \\
(.061)\end{array}$ & $\begin{array}{l}.105 \\
(.042)\end{array}$ & $\begin{array}{c}.196 \\
(.061)\end{array}$ & $\begin{array}{l}.106 \\
(.044)\end{array}$ \\
\hline $\begin{aligned} \text { Furniture } . . & \times \text { Compliance (binary) } \\
& \times \text { Compliance }(A-D)\end{aligned}$ & $\begin{array}{l}-.012 \\
(.109)\end{array}$ & $\begin{array}{l}.047 \\
(.076)\end{array}$ & $\begin{array}{l}-.022 \\
(.109)\end{array}$ & $\begin{array}{c}.042 \\
(.079)\end{array}$ \\
\hline $\begin{aligned} \text { Toys } & \times \text { Compliance (binary) } \\
& \times \text { Compliance }(\mathrm{A}-\mathrm{D})\end{aligned}$ & $\begin{array}{l}.065 \\
(.103)\end{array}$ & $\begin{array}{l}.070 \\
(.078)\end{array}$ & $\begin{array}{c}.051 \\
(.103)\end{array}$ & $\begin{array}{l}.031 \\
(.079)\end{array}$ \\
\hline $\begin{aligned} \text { Cookware } & \times \text { Compliance (binary) } \\
& \times \text { Compliance }(\mathrm{A}-\mathrm{D})\end{aligned}$ & $\begin{array}{l}.030 \\
(.113)\end{array}$ & $\begin{array}{l}.004 \\
(.083)\end{array}$ & $\begin{array}{l}.030 \\
(.112)\end{array}$ & $\begin{array}{l}.021 \\
(.086)\end{array}$ \\
\hline $\begin{aligned} \text { Other prod. } & \times \text { Compliance (binary) } \\
& \times \text { Compliance }(\mathrm{A}-\mathrm{D})\end{aligned}$ & $\begin{array}{l}.060 \\
(.294)\end{array}$ & $\begin{array}{l}-.020 \\
(.216)\end{array}$ & $\begin{array}{l}.063 \\
(.299)\end{array}$ & $\begin{array}{l}.066 \\
(.234)\end{array}$ \\
\hline Performance controls & $\checkmark$ & $\checkmark$ & $\checkmark$ & $\checkmark$ \\
\hline $\begin{array}{l}\text { Factory fixed effects } \\
\text { Year fixed effects }\end{array}$ & $\begin{array}{l}\checkmark \\
\checkmark\end{array}$ & $\begin{array}{l}\checkmark \\
\checkmark\end{array}$ & $\begin{array}{l}\checkmark \\
\checkmark\end{array}$ & $\begin{array}{l}\checkmark \\
\checkmark\end{array}$ \\
\hline Constant & $\begin{array}{c}6.8 \\
(.193)\end{array}$ & $\begin{array}{c}6.7 \\
(.196)\end{array}$ & $\begin{array}{l}7.4 \\
(.357)\end{array}$ & $\begin{array}{l}7.3 \\
(.359)\end{array}$ \\
\hline $\begin{array}{l}\text { Observations } \\
\text { R-squared } \\
\text { Factories }\end{array}$ & $\begin{array}{l}6,915 \\
.005 \\
2,447\end{array}$ & $\begin{array}{l}6,915 \\
.005 \\
2,447\end{array}$ & $\begin{array}{c}3,235 \\
.011 \\
1,028\end{array}$ & $\begin{array}{c}3,235 \\
.009 \\
1,028\end{array}$ \\
\hline
\end{tabular}

Notes. OLS panel fixed effects regression from 2009 to 2012, showing heterogeneous effects by factory industry. Models (1) - (2) fit using main panel of factories with performance data (Table A1). Models (3) - (4) fit on subsample of the main panel that undergoes a transition in compliance status over the period studied. Standard errors clustered by factory in parentheses. 


\section{Online Appendix: Additional Tables and Figures}

These appendices present supplementary analysis for Distelhorst, G. and Locke, R. "Does Compliance Pay?" American Journal of Political Science.

Table A1: Factory sourcing and compliance panel, 2009-2012

\begin{tabular}{|c|c|c|c|c|}
\hline Variable & Mean & $\mathrm{SD}$ & Min & Max \\
\hline \multicolumn{5}{|l|}{ Sourcing } \\
\hline Annual order value (thousand USD) & 3026 & 5212 & 0 & 46440 \\
\hline Logged annual order value & 6.61 & 2.12 & 0 & 10.75 \\
\hline \multicolumn{5}{|l|}{ Compliance } \\
\hline Compliance grade $(A=3 \ldots D=0)$ & 1.39 & .65 & 0 & 3 \\
\hline Compliance binary $(\mathrm{AB}=1, \mathrm{CD}=0)$ & .28 & .45 & 0 & 1 \\
\hline \multicolumn{5}{|l|}{ Compliance by audit item } \\
\hline Health \& Safety & .27 & .39 & 0 & 1 \\
\hline Work Hours & .54 & 47 & 0 & 1 \\
\hline Wages \& Benefits & .55 & .46 & 0 & 1 \\
\hline Management & .64 & .44 & 0 & 1 \\
\hline Environmental & .73 & .42 & 0 & 1 \\
\hline Legal (permits etc.) & .77 & .4 & 0 & 1 \\
\hline Freedom of Association & .95 & .22 & 0 & 1 \\
\hline Discipline practices & .96 & 18 & 0 & 1 \\
\hline Illegal labor & .96 & 18 & 0 & 1 \\
\hline Subcontracting & .98 & .12 & 0 & 1 \\
\hline Child labor & .99 & .08 & 0 & 1 \\
\hline Forced labor & .99 & .1 & 0 & 1 \\
\hline Discrimination & .99 & .11 & 0 & 1 \\
\hline \multicolumn{5}{|l|}{ Factory location } \\
\hline China & .58 & .49 & 0 & 1 \\
\hline India & .09 & .28 & 0 & 1 \\
\hline Bangladesh & .06 & .23 & 0 & 1 \\
\hline Vietnam & .05 & .21 & 0 & 1 \\
\hline Indonesia & .04 & .19 & 0 & 1 \\
\hline Thailand & .03 & .17 & 0 & 1 \\
\hline Turkey & .02 & .15 & 0 & 1 \\
\hline Philippines & .02 & .14 & 0 & 1 \\
\hline Taiwan & .02 & .14 & 0 & 1 \\
\hline Cambodia & .02 & .14 & 0 & 1 \\
\hline Pakistan & .01 & .1 & 0 & 1 \\
\hline (Others) & .06 & .24 & 0 & 1 \\
\hline \multicolumn{5}{|l|}{ Factory products } \\
\hline Clothing & .58 & .49 & 0 & 1 \\
\hline Furniture \& home decor & .26 & .44 & 0 & 1 \\
\hline Toys & .18 & .39 & 0 & 1 \\
\hline Cookware & .14 & .35 & 0 & 1 \\
\hline (Others) & .09 & .28 & 0 & 1 \\
\hline \multicolumn{5}{|l|}{ Factory size and performance } \\
\hline Employees & 660 & 979 & 3 & 13,221 \\
\hline On time delivery (\%) & .72 & .26 & 0 & 1 \\
\hline Quality inspection pass rate (\%) & .92 & .13 & 0 & 1 \\
\hline Total factories & 2,447 & & & \\
\hline Total observations & 6,915 & & & \\
\hline
\end{tabular}


Table A2: Labor rights and exports in sourcing agent data

\begin{tabular}{|c|c|c|c|c|c|c|c|c|}
\hline \multicolumn{5}{|c|}{ Fundamental labor rights } & \multicolumn{4}{|c|}{ Freedom of association/assembly } \\
\hline \multicolumn{2}{|c|}{ Export value } & Country & USD (m) & $\%$ & & Country & $\mathrm{USD}(\mathrm{m})$ & $\%$ \\
\hline \multirow{6}{*}{$\begin{array}{l}\text { Top } \\
\text { quartile }\end{array}$} & \multirow{6}{*}{$1 \%$} & Brazil & 3.9 & .01 & \multirow{6}{*}{$6 \%$} & Dom. Rep. & 20.7 & .07 \\
\hline & & Hong Kong & 11.3 & .04 & & Indonesia & 1458.7 & 4.97 \\
\hline & & Korea & 61.8 & .21 & & Korea & 61.8 & .21 \\
\hline & & Madagascar & 25.1 & .09 & & Peru & 10.7 & .04 \\
\hline & & Poland & 3.5 & .01 & & Poland & 3.5 & .01 \\
\hline & & Sri Lanka & 248.8 & .85 & & Portugal & 147.4 & .50 \\
\hline \multirow{8}{*}{$\begin{array}{l}\text { 2nd } \\
\text { quartile }\end{array}$} & \multirow{8}{*}{$5 \%$} & Dom. Rep. & 20.7 & .07 & \multirow{8}{*}{$10 \%$} & Brazil & 3.9 & .01 \\
\hline & & Mexico & 167.4 & .57 & & El Salvador & 7.9 & .03 \\
\hline & & Morocco & 10.5 & .04 & & India & 1701.4 & 5.79 \\
\hline & & Nicaragua & 74.5 & .25 & & Kenya & 78.3 & .27 \\
\hline & & Philippines & 549.0 & 1.87 & & Morocco & 10.5 & .04 \\
\hline & & Portugal & 147.4 & .50 & & Philippines & 549.0 & 1.87 \\
\hline & & Thailand & 594.6 & 2.02 & & Thailand & 594.6 & 2.02 \\
\hline & & Ukraine & 13.1 & .04 & & & & \\
\hline \multirow{11}{*}{$\begin{array}{l}\text { 3rd } \\
\text { quartile }\end{array}$} & \multirow{11}{*}{$69 \%$} & Cambodia & 998.7 & 3.40 & \multirow{11}{*}{$4 \%$} & Colombia & 23.2 & .08 \\
\hline & & China & 15818.8 & 53.86 & & Egypt & 91.1 & .31 \\
\hline & & Colombia & 23.2 & .08 & & Georgia & 9.1 & .03 \\
\hline & & El Salvador & 7.9 & .03 & & Guatemala & 446.0 & 1.52 \\
\hline & & Georgia & 9.1 & .03 & & Jordan & 267.9 & .91 \\
\hline & & India & 1701.4 & 5.79 & & Macedonia & 10.4 & .04 \\
\hline & & Indonesia & 1458.7 & 4.97 & & Madagascar & 25.1 & .09 \\
\hline & & Macedonia & 10.4 & .04 & & Mexico & 167.4 & .57 \\
\hline & & Malaysia & 283.8 & .97 & & Sri Lanka & 248.8 & .85 \\
\hline & & Tunisia & 9.1 & .03 & & Tunisia & 9.1 & .03 \\
\hline & & & & & & Ukraine & 13.1 & .04 \\
\hline \multirow{9}{*}{$\begin{array}{l}\text { Bottom } \\
\text { quartile }\end{array}$} & \multirow{9}{*}{$22 \%$} & Bangladesh & 2013.0 & 6.85 & \multirow{9}{*}{$78 \%$} & Bangladesh & 2013.0 & 6.85 \\
\hline & & Egypt & 91.1 & .31 & & Cambodia & 998.7 & 3.40 \\
\hline & & Guatemala & 446.0 & 1.52 & & China & 15818.8 & 53.86 \\
\hline & & Jordan & 267.9 & .91 & & Hong Kong & 11.3 & .04 \\
\hline & & Kenya & 78.3 & .27 & & Malaysia & 283.8 & .97 \\
\hline & & Pakistan & 188.0 & .64 & & Nicaragua & 74.5 & .25 \\
\hline & & Peru & 10.7 & .04 & & Pakistan & 188.0 & .64 \\
\hline & & Turkey & 955.2 & 3.25 & & Turkey & 955.2 & 3.25 \\
\hline & & Vietnam & 2545.5 & 8.67 & & Vietnam & 2545.5 & 8.67 \\
\hline
\end{tabular}

Notes. Share of export transactions originating from each country, sorted by level of respect for labor rights and freedom of association in sourcing agent database, 2009-2012. Ratings of labor rights and freedom of association from the World Justice Project, 2012-2013. Percentages sum to less than unity because thirteen countries present in the sourcing dataset are omitted from the World Justice Project: Bahrain, Haiti, Honduras, Laos, Lesotho, Lithuania, Macau, Mauritius, Oman, Slovakia, Swaziland, Taiwan, and Turkmenistan. Countries with less than 1m USD total export value also excluded from this table. 
Table A3: Cross-sectional analysis of order value and compliance (2012)

\begin{tabular}{|c|c|c|}
\hline DV & $\begin{array}{c}(1) \\
\text { Logged order value } \\
\text { (thousand USD) }\end{array}$ & $\begin{array}{c}(2) \\
\text { Order value } \\
\text { (thousand USD) }\end{array}$ \\
\hline Compliance & $\begin{array}{l}.612 \\
(.069)\end{array}$ & $\begin{array}{c}926 \\
(202) \\
\end{array}$ \\
\hline \multicolumn{3}{|l|}{ Factory location } \\
\hline China & $\begin{array}{l}.129 \\
(.154)\end{array}$ & $\begin{array}{l}-21 \\
(471)\end{array}$ \\
\hline India & $\begin{array}{l}-.570 \\
(.172)\end{array}$ & $\begin{array}{c}-1,965 \\
(485)\end{array}$ \\
\hline Bangladesh & $\begin{array}{l}-.094 \\
(.198)\end{array}$ & $\begin{array}{c}-2,108 \\
(583)\end{array}$ \\
\hline Indonesia & $\begin{array}{l}.017 \\
(.197)\end{array}$ & $\begin{array}{l}-823 \\
(623)\end{array}$ \\
\hline Vietnam & $\begin{array}{l}.426 \\
(.193)\end{array}$ & $\begin{array}{c}910 \\
(693)\end{array}$ \\
\hline Thailand & $\begin{array}{l}-.289 \\
(.222)\end{array}$ & $\begin{array}{l}-692 \\
(626)\end{array}$ \\
\hline Turkey & $\begin{array}{l}-.036 \\
(.255)\end{array}$ & $\begin{array}{l}-570 \\
(655)\end{array}$ \\
\hline Philippines & $\begin{array}{l}-.067 \\
(.280)\end{array}$ & $\begin{array}{c}541 \\
(746)\end{array}$ \\
\hline Taiwan & $\begin{array}{l}-.839 \\
(.268)\end{array}$ & $\begin{array}{c}-1,025 \\
(584)\end{array}$ \\
\hline Cambodia & $\begin{array}{l}.467 \\
(.345)\end{array}$ & $\begin{array}{c}936 \\
(1,169)\end{array}$ \\
\hline Pakistan & $\begin{array}{l}-.390 \\
(.347) \\
\end{array}$ & $\begin{array}{c}-2,212 \\
(804) \\
\end{array}$ \\
\hline \multicolumn{3}{|l|}{ Factory products } \\
\hline Clothing & $\begin{array}{l}1.715 \\
(.090)\end{array}$ & $\begin{array}{l}2,771 \\
(202)\end{array}$ \\
\hline Furniture \& home decor & $\begin{array}{l}.365 \\
(.086)\end{array}$ & $\begin{array}{c}282 \\
(172)\end{array}$ \\
\hline Toys & $\begin{array}{l}.195 \\
(.092)\end{array}$ & $\begin{array}{l}-649 \\
(186)\end{array}$ \\
\hline Cookware & $\begin{array}{l}.115 \\
(.098)\end{array}$ & $\begin{array}{l}-85 \\
(162)\end{array}$ \\
\hline Other products & $\begin{array}{l}.156 \\
(.107)\end{array}$ & $\begin{array}{l}-92 \\
(201)\end{array}$ \\
\hline \multicolumn{3}{|c|}{ Factory size and performance } \\
\hline Employees & $\begin{array}{c}.000 \\
(.000)\end{array}$ & $\begin{array}{l}1.543 \\
(.205)\end{array}$ \\
\hline On-time delivery & $\begin{array}{l}.192 \\
(.117)\end{array}$ & $\begin{array}{c}971 \\
(212)\end{array}$ \\
\hline Quality inspection & $\begin{array}{l}.886 \\
(.188)\end{array}$ & $\begin{array}{l}2,071 \\
(336)\end{array}$ \\
\hline Constant & $\begin{array}{l}4.124 \\
(.246)\end{array}$ & $\begin{array}{c}-1,815 \\
(572)\end{array}$ \\
\hline Observations & 4,309 & 4,309 \\
\hline R-squared & .215 & .208 \\
\hline
\end{tabular}

Notes. OLS regression on factory data from 2012. Robust standard errors in parentheses. 
Table A4: Main results: robustness with additional controls

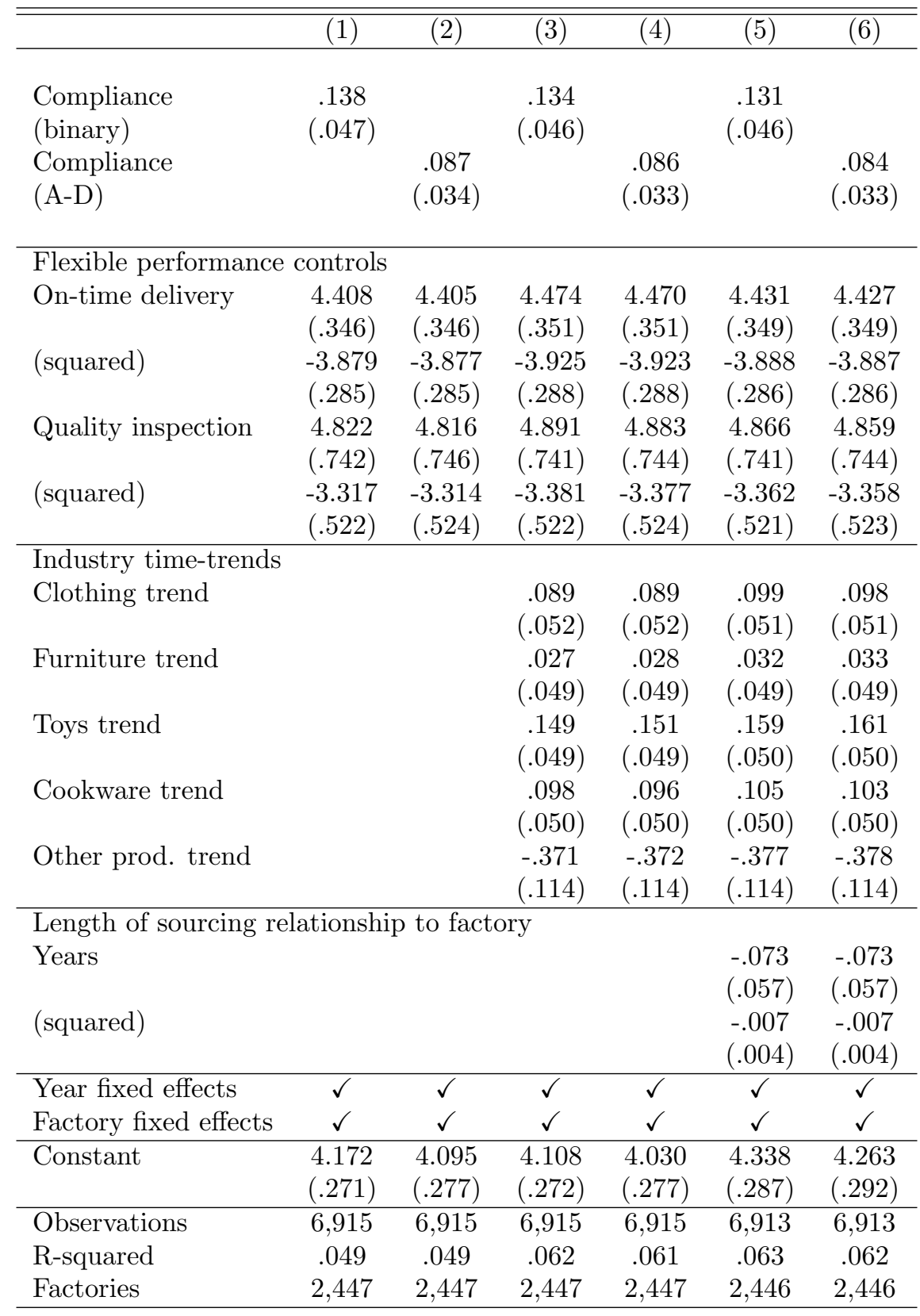

Notes. Replicating main effects of compliance on order value (logged USD, thousands) reported in Table 2 adding controls for non-linear relationship between performance metrics and purchasing, industry-specific trends in purchasing, and the length of the business relationship between factory and sourcing agent. Standard errors clustered by factory in parentheses. 
Table A5: Linear probability models of exceeding order value thresholds

\begin{tabular}{|c|c|c|c|c|c|c|c|c|c|}
\hline & $(1)$ & $(2)$ & $(3)$ & $(4)$ & $(5)$ & $(6)$ & $(7)$ & $(8)$ & $(9)$ \\
\hline $\begin{array}{l}\text { Binary dependent variables: } \\
\text { Order value greater than... }\end{array}$ & $\$ 0$ & $\$ 50,000$ & $\$ 100,000$ & $\$ 250,000$ & $\$ 500,000$ & $\$ 750,000$ & $\$ 1,000,000$ & $\$ 5,000,000$ & $\$ 10,000,000$ \\
\hline $\begin{array}{l}\text { Compliance } \\
\text { (binary) }\end{array}$ & $\begin{array}{l}.005 \\
(.005)\end{array}$ & $\begin{array}{l}.019 \\
(.008)\end{array}$ & $\begin{array}{l}.031 \\
(.010)\end{array}$ & $\begin{array}{l}.048 \\
(.012)\end{array}$ & $\begin{array}{l}.030 \\
(.012)\end{array}$ & $\begin{array}{l}.027 \\
(.013)\end{array}$ & $\begin{array}{l}.011 \\
(.013)\end{array}$ & $\begin{array}{l}.006 \\
(.009)\end{array}$ & $\begin{array}{l}.001 \\
(.007)\end{array}$ \\
\hline On-time delivery & $\begin{array}{l}-.012 \\
(.009)\end{array}$ & $\begin{array}{l}.006 \\
(.026)\end{array}$ & $\begin{array}{l}.034 \\
(.031)\end{array}$ & $\begin{array}{l}-.000 \\
(.031)\end{array}$ & $\begin{array}{l}-.027 \\
(.030)\end{array}$ & $\begin{array}{l}-.022 \\
(.029)\end{array}$ & $\begin{array}{l}-.030 \\
(.028)\end{array}$ & $\begin{array}{l}-.020 \\
(.014)\end{array}$ & $\begin{array}{c}.007 \\
(.008)\end{array}$ \\
\hline Quality inspection & $\begin{array}{l}-.002 \\
(014)\end{array}$ & $\begin{array}{l}-.056 \\
(046)\end{array}$ & $\begin{array}{c}.010 \\
(056)\end{array}$ & $\begin{array}{r}-.017 \\
(057)\end{array}$ & -.045 & -.022 & .001 & .016 & $\begin{array}{c}-.006 \\
(012)\end{array}$ \\
\hline 2010 fixed effect & $\begin{array}{l}(.014) \\
-.023 \\
(.005)\end{array}$ & $\begin{array}{l}(.040) \\
-.022 \\
(.009)\end{array}$ & $\begin{array}{l}(.056) \\
-.013 \\
(.011)\end{array}$ & $\begin{array}{l}.057) \\
.008 \\
(.012)\end{array}$ & $\begin{array}{l}(.052) \\
.023 \\
(.013)\end{array}$ & $\begin{array}{l}(.048) \\
.028 \\
(.013)\end{array}$ & $\begin{array}{l}(.044) \\
.034 \\
(.013)\end{array}$ & $\begin{array}{l}(.024) \\
.035 \\
(.009)\end{array}$ & $\begin{array}{l}(.012) \\
.025 \\
(.007)\end{array}$ \\
\hline 2011 fixed effect & $\begin{array}{l}-.048 \\
(.006)\end{array}$ & $\begin{array}{l}-.038 \\
(.010)\end{array}$ & $\begin{array}{l}-.025 \\
(.011)\end{array}$ & $\begin{array}{c}.003 \\
(.014)\end{array}$ & $\begin{array}{c}.024 \\
(.014)\end{array}$ & $\begin{array}{c}.027 \\
(.014)\end{array}$ & $\begin{array}{l}.025 \\
(.014)\end{array}$ & $\begin{array}{l}.042 \\
(.010)\end{array}$ & $\begin{array}{c}.032 \\
(.008)\end{array}$ \\
\hline 2012 fixed effect & $\begin{array}{l}-.066 \\
(.007) \\
\end{array}$ & $\begin{array}{l}-.057 \\
(.010) \\
\end{array}$ & $\begin{array}{l}-.038 \\
(.012) \\
\end{array}$ & $\begin{array}{c}.008 \\
(.014) \\
\end{array}$ & $\begin{array}{c}.035 \\
(.015) \\
\end{array}$ & $\begin{array}{c}.055 \\
(.015) \\
\end{array}$ & $\begin{array}{c}.054 \\
(.015) \\
\end{array}$ & $\begin{array}{c}.062 \\
(.011) \\
\end{array}$ & $\begin{array}{c}.038 \\
(.008) \\
\end{array}$ \\
\hline Factory fixed effects & $\checkmark$ & $\checkmark$ & $\checkmark$ & $\checkmark$ & $\checkmark$ & $\checkmark$ & $\checkmark$ & $\checkmark$ & $\checkmark$ \\
\hline Constant & $\begin{array}{l}1.016 \\
(.014)\end{array}$ & $\begin{array}{c}.976 \\
(.044) \\
\end{array}$ & $\begin{array}{c}.818 \\
(.055)\end{array}$ & $\begin{array}{c}.706 \\
(.057)\end{array}$ & $\begin{array}{c}.623 \\
(.052)\end{array}$ & $\begin{array}{l}.511 \\
(.048)\end{array}$ & $\begin{array}{c}.439 \\
(.046)\end{array}$ & $\begin{array}{l}.112 \\
(.024)\end{array}$ & $\begin{array}{c}.037 \\
(.014)\end{array}$ \\
\hline $\begin{array}{l}\text { Observations } \\
\text { R-squared } \\
\text { Factories }\end{array}$ & $\begin{array}{c}6,915 \\
.027 \\
2,447\end{array}$ & $\begin{array}{c}6,915 \\
.010 \\
2,447\end{array}$ & $\begin{array}{c}6,915 \\
.005 \\
2,447\end{array}$ & $\begin{array}{c}6,915 \\
.004 \\
2,447\end{array}$ & $\begin{array}{c}6,915 \\
.003 \\
2,447\end{array}$ & $\begin{array}{l}6,915 \\
.005 \\
2,447\end{array}$ & $\begin{array}{c}6,915 \\
.005 \\
2,447\end{array}$ & $\begin{array}{c}6,915 \\
.010 \\
2,447\end{array}$ & $\begin{array}{c}6,915 \\
.008 \\
2,447\end{array}$ \\
\hline
\end{tabular}

Notes. OLS panel fixed effects regression from 2009 to 2012. Dependent variables are binary indicators of whether each factory exceeded various thresholds of annual order value. The thresholds are defined by the annual order value bins defined by the sourcing agent in their data disclosure. Standard errors clustered by factory in parentheses. 
Table A6: Pre- and post-entropy-balancing covariate means

\begin{tabular}{|c|c|c|c|c|c|c|}
\hline & \multicolumn{3}{|c|}{ Factory Panel A: Decliners } & \multicolumn{3}{|c|}{ Factory Panel B: Improvers } \\
\hline & \multirow{2}{*}{ Stays compliant } & \multicolumn{2}{|c|}{ Declines } & \multirow{2}{*}{ Improves } & \multicolumn{2}{|c|}{ Stays noncompliant } \\
\hline & & Unweighted & Weighted & & Unweighted & Weighted \\
\hline 2009-2010 panel & & & & & & \\
\hline $\ln (2009$ order value $)$ & 4.199 & 3.696 & 4.199 & 3.322 & 2.968 & 3.322 \\
\hline Bangladesh & .06 & .04 & .06 & .028 & .059 & .028 \\
\hline Cambodia & .016 & .03 & .016 & .026 & .008 & .026 \\
\hline China & .42 & .542 & .42 & .621 & .583 & .621 \\
\hline India & .113 & .086 & .113 & .07 & .084 & .07 \\
\hline Indonesia & .019 & .076 & .019 & .038 & .072 & .038 \\
\hline Pakistan & .005 & .01 & .005 & .002 & .01 & .002 \\
\hline Philippines & .005 & .033 & .005 & .011 & .021 & .011 \\
\hline Taiwan & .027 & .023 & .027 & .032 & .012 & .032 \\
\hline Thailand & .038 & .02 & .038 & .021 & .035 & .021 \\
\hline Turkey & .03 & .013 & .03 & .013 & .019 & .013 \\
\hline Vietnam & .11 & .05 & .11 & .06 & .042 & .06 \\
\hline Clothing & .736 & .741 & .736 & .632 & .533 & .632 \\
\hline Cookware & .129 & .106 & .129 & .126 & .127 & .126 \\
\hline Furniturehomedec & .176 & .173 & .176 & .209 & .254 & .209 \\
\hline Toys & .129 & .136 & .129 & .179 & .158 & .179 \\
\hline Other products & .085 & .07 & .085 & .102 & .147 & .102 \\
\hline 2010-2011 panel & & & & & & \\
\hline $\ln (2010$ order value $)$ & 4.708 & 4.27 & 4.707 & 3.984 & 3.717 & 3.981 \\
\hline Pre-trend (2009-2010) & .336 & .476 & .336 & .34 & .197 & .34 \\
\hline Bangladesh & .023 & .067 & .023 & .016 & .074 & .017 \\
\hline Cambodia & .029 & .015 & .029 & .013 & .012 & .013 \\
\hline China & .485 & .581 & .485 & .564 & .54 & .563 \\
\hline India & .076 & .101 & .076 & .095 & .085 & .095 \\
\hline Indonesia & .029 & .032 & .029 & .059 & .088 & .059 \\
\hline Pakistan & 0 & .005 & 0 & .013 & .009 & .013 \\
\hline Philippines & .009 & .01 & .009 & .026 & .026 & .026 \\
\hline Taiwan & .049 & .02 & .049 & .026 & .009 & .026 \\
\hline Thailand & .026 & .027 & .026 & .026 & .043 & .026 \\
\hline Turkey & .029 & .01 & .029 & .02 & .02 & .02 \\
\hline Vietnam & .09 & .069 & .09 & .046 & .045 & .046 \\
\hline Clothing & .689 & .704 & .689 & .666 & .601 & .665 \\
\hline Cookware & .148 & .133 & .148 & .108 & .141 & .108 \\
\hline Furniture & .221 & .207 & .221 & .243 & .252 & .243 \\
\hline Toys & .166 & .163 & .166 & .216 & .156 & .216 \\
\hline Other products & .078 & .059 & .078 & .092 & .087 & .092 \\
\hline 2011-2012 panel & & & & & & \\
\hline $\ln (2011$ order value $)$ & 4.199 & 3.972 & 4.199 & 3.648 & 3.617 & 3.647 \\
\hline Pre-trend (2010-2011) & .558 & .284 & .558 & .271 & .373 & .271 \\
\hline Bangladesh & .013 & .03 & .013 & .011 & .105 & .011 \\
\hline Cambodia & .013 & .033 & .013 & .011 & .012 & .011 \\
\hline China & .503 & .605 & .503 & .569 & .574 & .568 \\
\hline India & .069 & .082 & .069 & .118 & .084 & .118 \\
\hline Indonesia & .044 & .052 & .044 & .052 & .071 & .052 \\
\hline Pakistan & .016 & .011 & .016 & .011 & .007 & .011 \\
\hline Philippines & .025 & .016 & .025 & .022 & .016 & .022 \\
\hline Taiwan & .053 & .027 & .053 & .03 & .005 & .03 \\
\hline Thailand & .022 & .027 & .022 & .033 & .037 & .033 \\
\hline Turkey & .025 & .025 & .025 & .014 & .016 & .014 \\
\hline Vietnam & .075 & .052 & .075 & .077 & .04 & .077 \\
\hline Clothing & .678 & .625 & .678 & .626 & .595 & .626 \\
\hline Cookware & .122 & .142 & .122 & .132 & .113 & .132 \\
\hline Furniture & .225 & .271 & .225 & .209 & .227 & .209 \\
\hline Toys & .188 & .23 & .188 & .168 & .163 & .168 \\
\hline Other products & .094 & .088 & .094 & .102 & .118 & .102 \\
\hline
\end{tabular}

Notes. Results of entropy balancing on pre-treatment covariates for the analyses reported in Figure 5 and Appendix Table A7. Left panel shows factories that start the panel compliant and either maintain compliance or fall out of compliance (decline). Right panel shows factories that start the panel noncompliant and either come into compliance (improve) or remain noncompliant. Reweighting the factory samples using entropy balancing (Hainmueller 2012) yields balanced samples on initial period order value, factory location, factory products, and pre-trends in purchasing (2010-2012 only). 
Table A7: Two-year panel models, original and entropy-balanced subsamples

\begin{tabular}{|c|c|c|c|c|c|c|c|c|c|c|c|c|}
\hline \multirow{2}{*}{$\begin{array}{l}\text { Panel } \\
\text { Subsample }\end{array}$} & \multicolumn{4}{|c|}{$2009-2010$} & \multicolumn{4}{|c|}{$2010-2011$} & \multicolumn{4}{|c|}{$2011-2012$} \\
\hline & $\begin{array}{c}\text { Original } \\
(1)\end{array}$ & $\begin{array}{c}\text { Improvers } \\
(2)\end{array}$ & $\begin{array}{c}\text { Decliners } \\
(3)\end{array}$ & $\begin{array}{c}\text { Combined } \\
(4)\end{array}$ & $\begin{array}{c}\text { Original } \\
(5)\end{array}$ & $\begin{array}{c}\text { Improvers } \\
(6)\end{array}$ & $\begin{array}{c}\text { Decliners } \\
(7)\end{array}$ & $\begin{array}{c}\text { Combined } \\
(8)\end{array}$ & $\begin{array}{c}\text { Original } \\
(9)\end{array}$ & $\begin{array}{c}\text { Improvers } \\
(10)\end{array}$ & $\begin{array}{c}\text { Decliners } \\
(11)\end{array}$ & $\begin{array}{c}\text { Combined } \\
(12)\end{array}$ \\
\hline Compliance & $\begin{array}{l}.136 \\
(.0569)\end{array}$ & $\begin{array}{l}.274 \\
(.0868)\end{array}$ & $\begin{array}{l}.128 \\
(.149)\end{array}$ & $\begin{array}{l}.121 \\
(.0665)\end{array}$ & $\begin{array}{l}.221 \\
(.0508)\end{array}$ & $\begin{array}{c}.195 \\
(.0789)\end{array}$ & $\begin{array}{c}.0836 \\
(.0931)\end{array}$ & $\begin{array}{c}.0813 \\
(.0482)\end{array}$ & $\begin{array}{l}.158 \\
(.123)\end{array}$ & $\begin{array}{l}.389 \\
(.247)\end{array}$ & $\begin{array}{l}.559 \\
(.334)\end{array}$ & $\begin{array}{l}.320 \\
(.160)\end{array}$ \\
\hline $2010 \mathrm{FE}$ & $\begin{array}{c}.279 \\
(.0328)\end{array}$ & $\begin{array}{l}.190 \\
(.0473)\end{array}$ & $\begin{array}{c}.367 \\
(.0926)\end{array}$ & $\begin{array}{c}.306 \\
(.0415)\end{array}$ & & & & & & & & \\
\hline $2011 \mathrm{FE}$ & & & & & $\begin{array}{c}.253 \\
(.0303)\end{array}$ & $\begin{array}{c}-.172 \\
(.0463)\end{array}$ & $\begin{array}{l}-.0594 \\
(.0592)\end{array}$ & $\begin{array}{l}-.0862 \\
(.0307)\end{array}$ & & & & \\
\hline $2012 \mathrm{FE}$ & & & & & & & & & $\begin{array}{c}3.183 \\
(.0654)\end{array}$ & $\begin{array}{l}3.062 \\
(.122)\end{array}$ & $\begin{array}{l}3.365 \\
(.234)\end{array}$ & $\begin{array}{l}3.166 \\
(.103)\end{array}$ \\
\hline Constant & $\begin{array}{c}3.267 \\
(.0225) \\
\end{array}$ & $\begin{array}{c}3.322 \\
(.0217) \\
\end{array}$ & $\begin{array}{l}4.071 \\
(.145)\end{array}$ & $\begin{array}{c}3.630 \\
(.0304)\end{array}$ & $\begin{array}{c}3.004 \\
(.0217) \\
\end{array}$ & $\begin{array}{c}3.983 \\
(.0197) \\
\end{array}$ & $\begin{array}{c}4.624 \\
(.0915) \\
\end{array}$ & $\begin{array}{c}4.324 \\
(.0279) \\
\end{array}$ & $\begin{array}{c}3.194 \\
(.0438)\end{array}$ & $\begin{array}{c}3.647 \\
(.0618) \\
\end{array}$ & $\begin{array}{l}3.640 \\
(.343)\end{array}$ & $\begin{array}{c}3.756 \\
(.0897) \\
\end{array}$ \\
\hline $\begin{array}{l}\text { Factory FE } \\
\text { Entropy balancing } \\
\text {...including pre-trends }\end{array}$ & $\checkmark$ & $\begin{array}{l}\checkmark \\
\checkmark\end{array}$ & $\begin{array}{l}\checkmark \\
\checkmark\end{array}$ & $\begin{array}{l}\checkmark \\
\checkmark\end{array}$ & $\checkmark$ & $\begin{array}{l} \\
\checkmark \\
\checkmark \\
\checkmark\end{array}$ & $\begin{array}{l} \\
\checkmark \\
\checkmark \\
\end{array}$ & $\begin{array}{l} \\
\checkmark \\
\checkmark \\
\end{array}$ & $\checkmark$ & $\begin{array}{l} \\
\checkmark \\
\checkmark \\
\end{array}$ & $\begin{array}{l}\checkmark \\
\checkmark \\
\checkmark\end{array}$ & $\begin{array}{l} \\
\checkmark \\
\checkmark \\
\end{array}$ \\
\hline Observations & 5,106 & 3,776 & 1,330 & 5,106 & 6,932 & 2,554 & 1,500 & 4,054 & 7,040 & 3,398 & 1,370 & 4,768 \\
\hline R-squared & .032 & .045 & .031 & .037 & .024 & .010 & .009 & .008 & .403 & .395 & .375 & .385 \\
\hline Number of fcode & 2,553 & 1,888 & 665 & 2,553 & 3,466 & 1,277 & 750 & 2,027 & 3,520 & 1,699 & 685 & 2,384 \\
\hline
\end{tabular}

Notes. OLS panel fixed effects regression in two-year panels. The dependent variable is logged annual order values in 2012 constant dollars. Regression coefficients shown with robust standard errors clustered by factory in parentheses. Columns 1 , 5 and 9 show the results from the unweighted panel data. Remaining columns estimated on factory subsamples reweighted by entropy balancing. 2009-2010 subsample balanced using initial-year order value, distribution of factory locations, and distribution of factory product-types. 2010-2011 and 2011-2012 include these variables and prior-year purchasing trends. (E.g. for 2010-2011, the pre-rend is the difference between 2009 and 2010 order value.) For these panels, the re-weighted samples have fewer observations because not all factories have prior-year orders to estimate trends. "Improvers" includes all factories that start the panel noncompliant (identified on factory transitions into compliance). "Decliners" includes all factories that start the panel compliant (identified on factory transitions out of compliance). Columns 4, 8, and 12 show estimates from the combined weighted samples. Note the increased $R^{2}$ in the 2011-2012 panel results from the large increase in total order value in 2012, variation that is explained by the year fixed effect. 
Table A8: Effects of individual compliance items on annual order value

\begin{tabular}{|c|c|c|}
\hline & (1) & $(2)$ \\
\hline \multirow[t]{2}{*}{ Child labor } & -0.29 & -0.29 \\
\hline & $(0.34)$ & $(0.34)$ \\
\hline \multirow[t]{2}{*}{ Illegal labor } & -0.17 & -0.17 \\
\hline & $(0.21)$ & $(0.21)$ \\
\hline \multirow[t]{2}{*}{ Forced labor } & -0.38 & -0.38 \\
\hline & $(0.41)$ & $(0.41)$ \\
\hline \multirow[t]{2}{*}{ Discipline practices } & 0.20 & 0.20 \\
\hline & $(0.18)$ & $(0.18)$ \\
\hline \multirow[t]{2}{*}{ Discrimination } & -0.05 & -0.05 \\
\hline & $(0.31)$ & $(0.31)$ \\
\hline \multirow[t]{2}{*}{ Health \& Safety } & 0.12 & 0.13 \\
\hline & $(0.07)$ & $(0.07)$ \\
\hline \multirow[t]{2}{*}{ Environmental } & 0.20 & 0.20 \\
\hline & $(0.09)$ & $(0.09)$ \\
\hline \multirow[t]{2}{*}{ Wages \& Benefits } & 0.15 & 0.15 \\
\hline & $(0.07)$ & $(0.07)$ \\
\hline \multirow[t]{2}{*}{ Work Hours } & -0.04 & -0.04 \\
\hline & $(0.08)$ & $(0.08)$ \\
\hline \multirow[t]{2}{*}{ Freedom of Association } & -0.05 & -0.05 \\
\hline & $(0.19)$ & $(0.19)$ \\
\hline \multirow[t]{2}{*}{ Legal (permits etc.) } & 0.12 & 0.12 \\
\hline & $(0.10)$ & $(0.10)$ \\
\hline \multirow[t]{2}{*}{ Subcontracting } & -0.17 & -0.17 \\
\hline & $(0.22)$ & $(0.22)$ \\
\hline \multirow[t]{2}{*}{ Management } & -0.08 & -0.08 \\
\hline & $(0.08)$ & $(0.08)$ \\
\hline \multirow[t]{2}{*}{ On-time delivery } & & -0.06 \\
\hline & & $(0.11)$ \\
\hline \multirow[t]{2}{*}{ Quality inspection } & & -0.01 \\
\hline & & $(0.19)$ \\
\hline Year FE & $\checkmark$ & $\checkmark$ \\
\hline Factory FE & $\checkmark$ & $\checkmark$ \\
\hline \multirow[t]{2}{*}{ Constant } & 7.25 & 7.32 \\
\hline & $(0.65)$ & $(0.68)$ \\
\hline Observations & 6,869 & 6,869 \\
\hline Factories & 2,346 & 2,346 \\
\hline
\end{tabular}

Notes. OLS panel fixed effects regression from 2009 to 2012. Dependent variable is $\ln$ (annual order value) in thousand USD in 2012 constant dollars. Model estimated: $Y_{i t}=\eta_{i}+\delta_{t}+\beta_{1}$ ChildLabor $_{i t}+\beta_{2}$ IllegalLabor $_{i t}+\ldots+\beta_{13}$ Management $_{i t}+\varepsilon_{i t}$ Standard errors clustered by factory in parentheses. 
Table A9: Full sample effects, China only, and rest of world

\begin{tabular}{|c|c|c|c|c|c|c|}
\hline & \multicolumn{2}{|c|}{ Main panel } & \multicolumn{2}{|c|}{ China only } & \multicolumn{2}{|c|}{ Rest of world } \\
\hline & $(1)$ & $(2)$ & $(3)$ & $(4)$ & $(5)$ & $(6)$ \\
\hline Compliance (binary) & $\begin{array}{c}.143 \\
(.048)\end{array}$ & & $\begin{array}{l}.159 \\
(.053)\end{array}$ & & $\begin{array}{c}.113 \\
(.090)\end{array}$ & \\
\hline Compliance (A-D) & & $\begin{array}{c}.093 \\
(.034)\end{array}$ & & $\begin{array}{c}.102 \\
(.041)\end{array}$ & & $\begin{array}{c}.080 \\
(.058)\end{array}$ \\
\hline On-time delivery & $\begin{array}{l}.072 \\
(.113)\end{array}$ & $\begin{array}{l}-.074 \\
(.113)\end{array}$ & $\begin{array}{c}.107 \\
(.161)\end{array}$ & $\begin{array}{c}.103 \\
(.161)\end{array}$ & $\begin{array}{l}-.267 \\
(.156)\end{array}$ & $\begin{array}{l}-.266 \\
(.156)\end{array}$ \\
\hline Quality inspection & $\begin{array}{l}-.087 \\
(.190)\end{array}$ & $\begin{array}{l}-.089 \\
(.190)\end{array}$ & $\begin{array}{l}-.028 \\
(.208)\end{array}$ & $\begin{array}{l}-.025 \\
(.208)\end{array}$ & $\begin{array}{l}-.276 \\
(.429)\end{array}$ & $\begin{array}{l}-.285 \\
(.427)\end{array}$ \\
\hline 2010.audityr & $\begin{array}{c}.015 \\
(.051)\end{array}$ & $\begin{array}{c}.017 \\
(.051)\end{array}$ & $\begin{array}{l}.099 \\
(.060)\end{array}$ & $\begin{array}{l}.103 \\
(.060)\end{array}$ & $\begin{array}{l}.099 \\
(.088)\end{array}$ & $\begin{array}{l}.099 \\
(.087)\end{array}$ \\
\hline 2011.audityr & $\begin{array}{l}-.105 \\
(.058)\end{array}$ & $\begin{array}{l}-.105 \\
(.058)\end{array}$ & $\begin{array}{l}-.027 \\
(.068)\end{array}$ & $\begin{array}{l}-.026 \\
(.068)\end{array}$ & $\begin{array}{l}-.205 \\
(.101)\end{array}$ & $\begin{array}{l}-.206 \\
(.102)\end{array}$ \\
\hline 2012.audityr & $\begin{array}{l}-.129 \\
(.062)\end{array}$ & $\begin{array}{l}-.129 \\
(.062)\end{array}$ & $\begin{array}{l}-.037 \\
(.076)\end{array}$ & $\begin{array}{l}-.033 \\
(.076)\end{array}$ & $\begin{array}{l}-.245 \\
(.103)\end{array}$ & $\begin{array}{l}-.247 \\
(.103)\end{array}$ \\
\hline Factory fixed effects & $\checkmark$ & $\checkmark$ & $\checkmark$ & $\checkmark$ & $\checkmark$ & $\checkmark$ \\
\hline Constant & $\begin{array}{c}6.8 \\
(.193) \\
\end{array}$ & $\begin{array}{c}6.7 \\
(.196) \\
\end{array}$ & $\begin{array}{c}6.4 \\
(.222) \\
\end{array}$ & $\begin{array}{c}6.3 \\
(.224) \\
\end{array}$ & $\begin{array}{r}7.3 \\
(.415) \\
\end{array}$ & $\begin{array}{c}7.2 \\
(.418) \\
\end{array}$ \\
\hline Obser & 6,915 & 6,915 & 4,040 & 4,040 & 2,875 & 2,875 \\
\hline R-squ & .005 & .005 & .006 & .005 & .008 & .008 \\
\hline Factories & 2,447 & 2,447 & 1,449 & 1,449 & 998 & 998 \\
\hline
\end{tabular}

Notes. OLS panel fixed effects regression from 2009 to 2012. Dependent variable is $\ln$ (annual order value) in thousand USD in 2012 constant dollars. Standard errors clustered by factory in parentheses. 
Table A10: Effects of compliance on order value by factory size

\begin{tabular}{lcccc}
\hline \hline & $(1)$ & $(2)$ & $(3)$ & $(4)$ \\
\hline & & & & \\
Small factory $\times$ compliance & .123 & .122 & .115 & .112 \\
& $(.060)$ & $(.060)$ & $(.060)$ & $(.060)$ \\
Large factory $\times$ compliance & .160 & .160 & .164 & .162 \\
& $(.071)$ & $(.071)$ & $(.071)$ & $(.071)$ \\
& & & & \\
On-time delivery & & -.041 & & -.205 \\
& & $(.114)$ & & $(.191)$ \\
Quality inspection & & -.131 & & -.406 \\
& & $(.191)$ & & $(.346)$ \\
2010 fixed effect & & & & \\
& .070 & .070 & .211 & .209 \\
2011 fixed effect & $(.052)$ & $(.052)$ & $(.069)$ & $(.069)$ \\
& -.040 & -.039 & .103 & .108 \\
2012 fixed effect & $(.063)$ & $(.063)$ & $(.084)$ & $(.083)$ \\
& -.068 & -.067 & .152 & .157 \\
Constant & $.063)$ & $(.063)$ & $(.084)$ & $(.083)$ \\
& 6.622 & 6.772 & 6.882 & 7.414 \\
& $(.044)$ & $(.196)$ & $(.057)$ & $(.361)$ \\
\hline Factory FE & $\checkmark$ & $\checkmark$ & $\checkmark$ & $\checkmark$ \\
\hline Observations & 6,646 & 6,646 & 3,225 & 3,225 \\
Factories & 2,335 & 2,335 & 1,024 & 1,024 \\
\hline
\end{tabular}

Notes. OLS panel fixed effects regression from 2009 to 2012. Dependent variable is $\ln$ (annual order value) in thousand USD. Small factories range from 4 to 293 employees. Large factories range from 293 to 11,105 employees. Size boundaries determined to create two factory pools of equal size. Standard errors clustered by factory in parentheses. 
Table A11: Effect magnitudes by factory size

\begin{tabular}{|c|c|c|c|c|}
\hline & Model 1 & Model 2 & Model 3 & Model 4 \\
\hline \multicolumn{5}{|c|}{ Small factories (4-293 employees) } \\
\hline $\begin{array}{l}\text { Point estimate } \\
\text { (thousand USD) }\end{array}$ & $\$ 97$ & $\$ 96$ & $\$ 134$ & $\$ 133$ \\
\hline $95 \%$ CI Lower & $\$ 4$ & $\$ 3$ & $-\$ 7$ & $-\$ 10$ \\
\hline 95\% CI Upper & $\$ 202$ & $\$ 202$ & $\$ 286$ & $\$ 288$ \\
\hline $\begin{array}{l}\text { Point estimate } \\
\text { (\% of order value) }\end{array}$ & $7.72 \%$ & $7.46 \%$ & $10.42 \%$ & $10.33 \%$ \\
\hline $95 \%$ CI Lower & $0.30 \%$ & $0.24 \%$ & $-0.54 \%$ & $-0.77 \%$ \\
\hline 95\% CI Upper & $15.85 \%$ & $15.85 \%$ & $22.51 \%$ & $22.59 \%$ \\
\hline \multicolumn{5}{|c|}{ Large factories (293-11,105 employees) } \\
\hline $\begin{array}{l}\text { Point estimate } \\
\text { (thousand USD) }\end{array}$ & $\$ 131$ & $\$ 131$ & $\$ 200$ & $\$ 202$ \\
\hline $95 \%$ CI Lower & $\$ 19$ & $\$ 19$ & $\$ 36$ & $\$ 37$ \\
\hline 95\% CI Upper & $\$ 256$ & $\$ 254$ & $\$ 382$ & $\$ 385$ \\
\hline $\begin{array}{l}\text { Point estimate } \\
\text { (\% of order value) }\end{array}$ & $3.19 \%$ & $3.18 \%$ & $4.86 \%$ & $4.90 \%$ \\
\hline 95\% CI Lower & $0.45 \%$ & $0.46 \%$ & $0.86 \%$ & $0.90 \%$ \\
\hline 95\% CI Upper & $6.31 \%$ & $6.25 \%$ & $9.48 \%$ & $9.54 \%$ \\
\hline
\end{tabular}

Notes. Effect magnitude estimates calculated from models fit in Appendix Table A10. Small factories average 124 employees. Large factories average 1,113 employees. Distributions obtained using the bootstrap method $(B=1,000)$. Results visualized in Figure 6 . 
Table A12: Effects of compliance by length of sourcing relationship

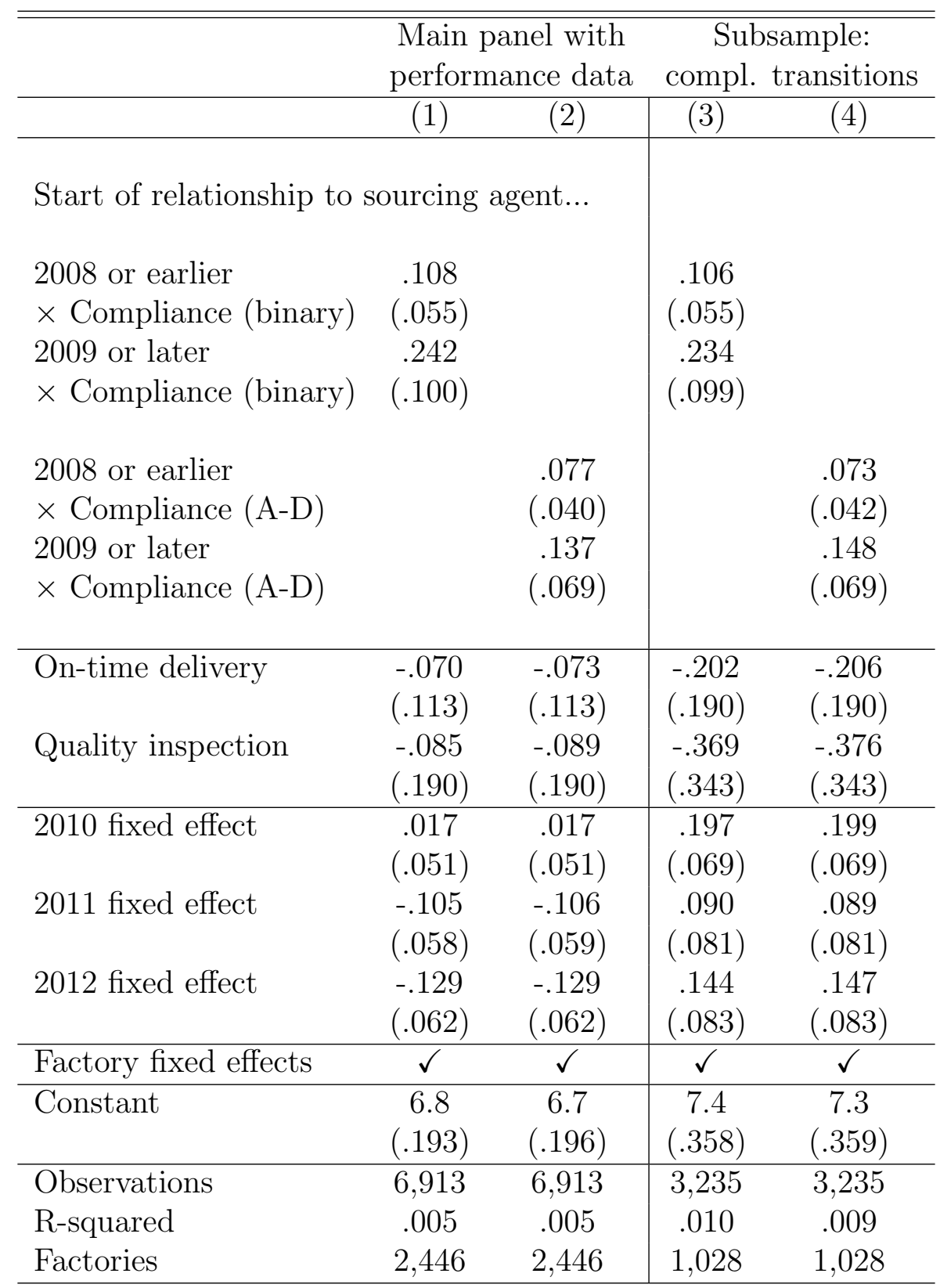

Notes. OLS panel fixed effects regression from 2009 to 2012. Dependent variable is $\ln$ (annual order value) in thousand USD. Factories divided into two groups based on whether the sourcing agent has imported from the factory in any year prior to the start of our panel (2009). Although effect magnitudes are larger for factories with shorter relationships, we cannot reject the hypothesis that effects are identical across the two groups. Standard errors clustered by factory in parentheses. 
Figure A1: Effects of compliance by audit item

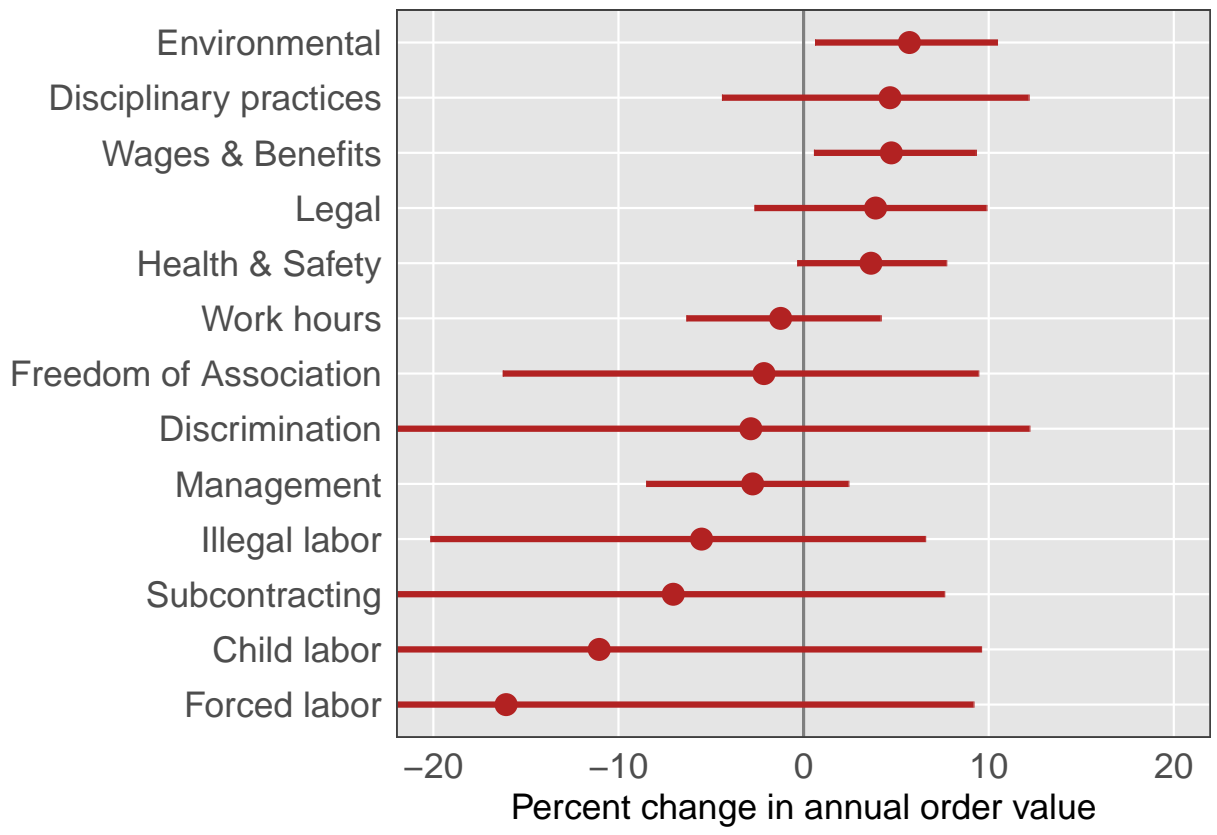

Notes. Estimated effects of compliance by audit item, estimated with the bootstrap method $(B=1,000)$ using panel estimations reported in Appendix Table A8. For completeness we include all thirteen indicators, although the confidence intervals for several low variance items are so large as to be able to say little about the direction or magnitude of the effect. Error bars show 95\% confidence intervals. 


\section{Appendix B: Effects of individual compliance items}

This section provides additional detail on the effects of individual compliance items reported in Figure A1 and Appendix Table A8, For many of the audit items, the estimated effects have very wide confidence intervals. This leads to great uncertainty about the direction and magnitude of effects of compliance items in freedom of association, discrimination, illegal labor, subcontracting, child labor, and forced labor. The imprecision of these estimates comes in part from the low variation in these items. Each has an average compliance rate of $95 \%$ or higher (Appendix Table A1). Given the widespread violations of freedom of association in countries like China, these compliance rates should be interpreted with great skepticism.

Figure B1: Auditor comments in environmental violations

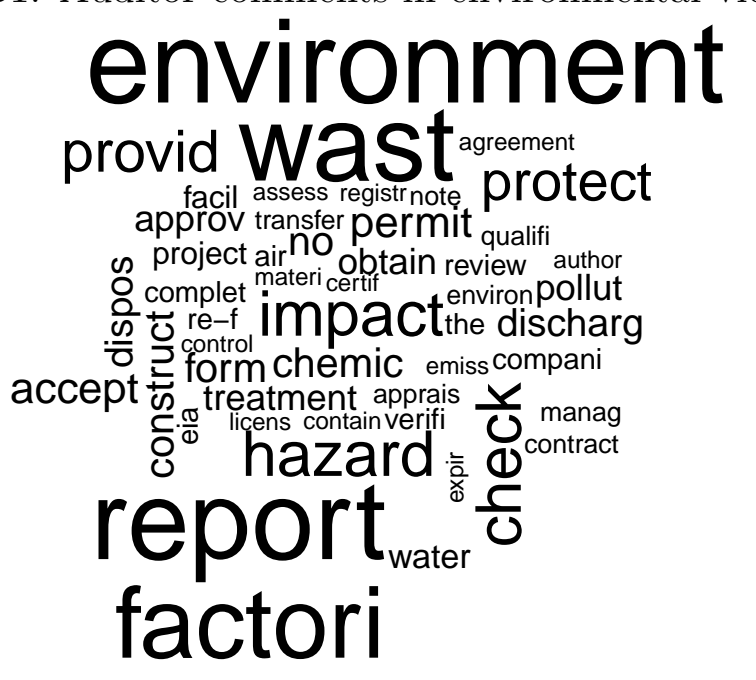

Notes. Word size corresponds to frequency of appearance in auditor comments when assessing noncompliance with environmental standards.

Environmental compliance is associated with a $6 \%$ annual increase in buyer orders (USD 155,000). The most common terms appearing in auditor comments appear in Figure B1. Environmental standards in these audits include obtaining the relevant permits from local regulators to certify a factory's environmental impact. They also cover the proper handling and disposal of hazardous waste. Auditor 
comments on environmental violations included: pollution control certificate expired; hazardous wastes not disposed by licensed contractor; discharges wastewater without treatment; and waste air from spraying workshop emitted to atmosphere without any proper treatment.

Compliance with wage and benefits standards is associated with a $5 \%$ increase in annual order value (USD 130,000). Wage standards include paying at least the local minimum wage, paying the appropriate premiums for overtime and weekend work, offering statutory social insurance benefits, and providing accurate records of worker wages (Figure B2). Example violations cited in audits include: lowest wages paid was RMB840/month, which was less than the local minimum wage standard; salary payment in Feb 2011 for employees who worked full month (24 days) was less than in labor contract; and factory calculated overtime compensation based on 208 working hours instead of 192 working hours.

Figure B2: Auditor comments in wage and benefit violations

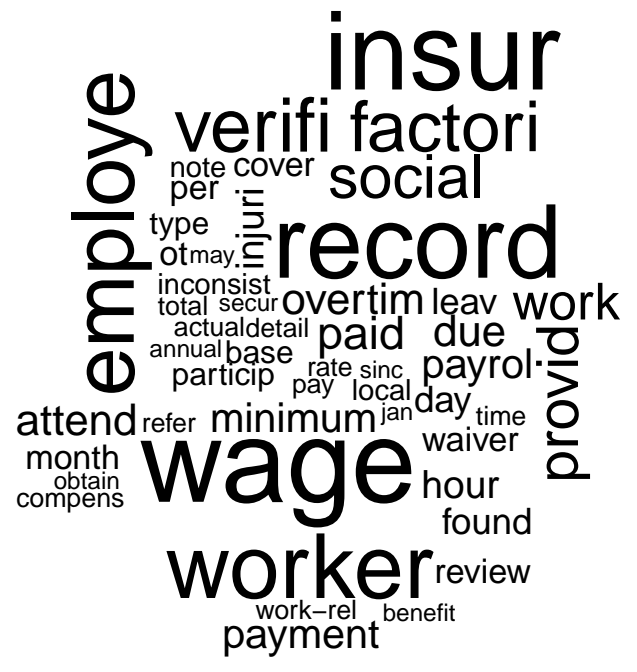

Notes. Word size corresponds to frequency of appearance in auditor comments when assessing noncompliance with wage and benefit standards.

A third predictor of increased order value is health and safety compliance (4\%, USD 98,000). This is the most complex standard in the audit, with over twenty 
Figure B3: Auditor comments in health and safety violations

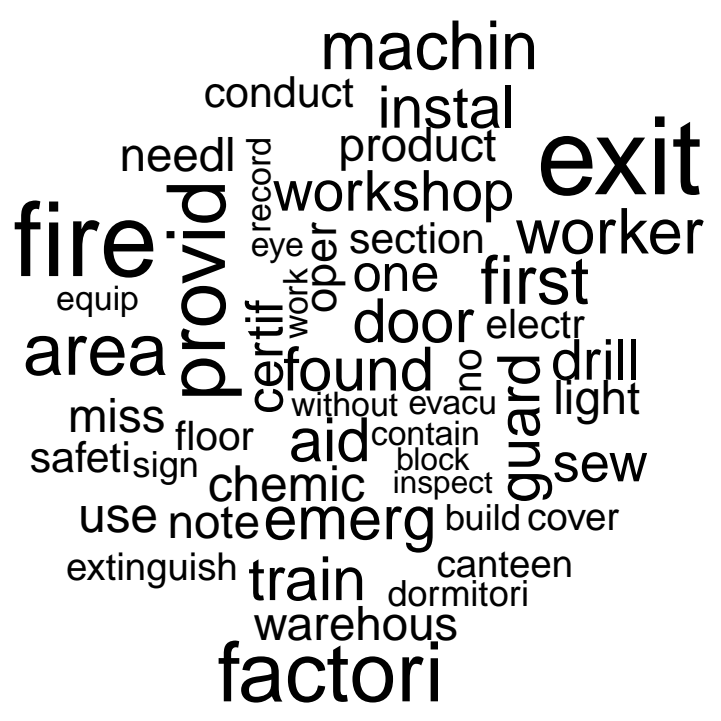

Notes. Word size corresponds to frequency of appearance in auditor comments when assessing noncompliance with health and safety standards.

subcategories. The most common terms in auditor comments appear in Figure B3. Disaster preparedness is one major component, including the accessibility of fire exits, emergency lighting, and fire-fighting equipment. Example violations included: Exit in the Finishing area blocked with finished goods; and No emergency lights... No fire alarm at dormitory. Another element of health and safety is the provision of personal protective equipment such as facemasks and the use of appropriate machine-guarding to prevent industrial accidents. Example findings included: All spraying operators work without respiratory mask; All sewing machines not equipped with needle guards; and No effective eye wash station was available in paint-spraying workshop. Buyer sensitivity to problems with workplace safety is unsurprising. Unsafe working conditions in recent years have cost hundreds of supply chain workers their lives, from the Rana Plaza factory collapse in Bangladesh to fatal factory explosions at electronics suppliers in China. However, the compliance item here focuses largely on disaster preparedness and safety around machines and chemicals, rather than the structural 
integrity of factory buildings.

Legal compliance exhibits a similar effect magnitude (4\%), but its $95 \%$ confidence interval crosses zero $(-2 \%, 9 \%)$. Legal compliance largely addresses two issues. First, it examines whether the factory has obtained the proper permits, licenses, and certificates. For example, one auditor reported: Found factory business license / tax certificate address not match with factory actual location. Second, legal compliance also records whether factory management attempted to deceive compliance auditors. Example violations included, 2 sets of time records found and Double book attendance records were found during the audit. The word cloud shows that these cases of detected deception are rarer than citations for licensing issues.

Finally, the point estimate for disciplinary measures compliance is similar to the others but imprecisely estimated, with a confidence interval ranging from $-4 \%$ to $12 \%$. Disciplinary practice standards forbid factories from using corporal punishment or public embarrassment as techniques for controlling employee behavior.

None of the effect estimates for the remaining predictors approach statistical significance. The insensitivity of buyer orders to work hours compliance despite a high rate of violations (46\%) merits some discussion. Most factories in the panel are located in China. Chinese labor laws permit just 36 hours of monthly overtime. However, workers (with an interest in maximizing earnings) and employers (with an interest in scaling production volumes without hiring new workers) often see benefit in violating these laws. In the absence of local regulatory enforcement, factories often aim for 60-80 hours of monthly overtime for production workers. Violations of China's work hours regulations are therefore often viewed as unremarkable. Indeed, we find that buyers appear to ignore these violations when making sourcing decisions.

Given the importance of freedom of association in activist critiques of global production, it may seem surprising that buyers are insensitive to this item. However, previous research suggests that freedom of association as measured by compliance 
auditing regimes is not particularly meaningful. Buyer-driven audits are unlikely to detect violations of association rights (Anner 2012), and compliance with freedom of association standards in labor repressive settings like China often may involve relatively superficial measures (Distelhorst et al. 2015). Indeed, the panel shows 95\% compliance with freedom of association standards despite a preponderance of factories in mainland China. These shortcomings may render buyers relatively indifferent to freedom of association findings in compliance audits. 